\title{
ANTECEDENT AND CONSEQUENTS OF ECO-INNOVATION FOR SUSTAINABILITY: GENERATIONS' PERCEPTIONS IN BRAZIL AND PORTUGAL
}

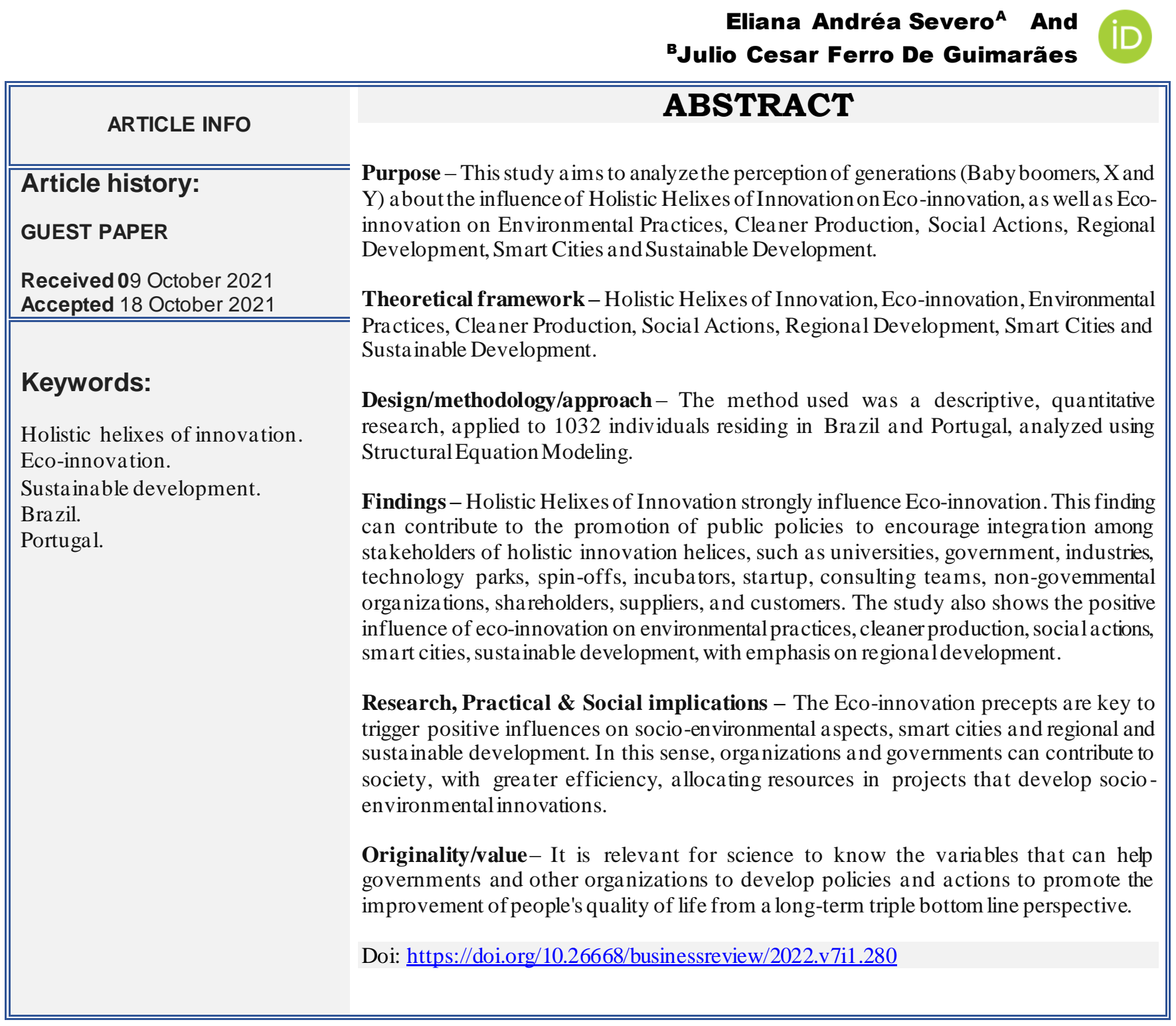

A Post-Doctoral degree from the University of Caxias do Sul (UCS), Brazil, Doctor in Business Administration at the Pontificia University Católica of Rio Grande do Sul (PUC-RS) Brazil and University of Caxias do Sul (UCS), Brazil. Master in Administration from UCS, Brazil. Specialization in Environmental Management with Emphasis on Industry by UCS. Graduated in Business Administration from University Vale do Rio dos Sinos (UNISINOS) Brazil. Graduation in Biological Sciences from the University of Santa Cruz do Sul (UNISC) Brazil. Email: elianasevero2@hotmail.com https://orcid.org/0000-0002-5970-4032

B Post-Doctoral degree from the University of Caxias do Sul (UCS), Brazil, Doctor in Business Administration at the Pontificia University Católica of Rio Grande do Sul (PUC-RS) Brazil and University of Caxias do Sul (UCS), Brazil. Master in Production Engineering by the Federal University of Rio Grande do Sul (UFRGS). Email: juliocfguimaraes@yahoo.com.br https://orcid.org/0000-0003-3718-6075 


\section{ANTECEDENTE E CONSEQUENTES DA ECO-INOVAÇÃo PARA A SUSTENTABILIDADE: PERCEPÇÕES DAS GERAÇÕES NO BRASIL E EM PORTUGAL}

Objetivo: Este estudo tem como objetivo a nalisar a percepção das gerações (Baby boomers, $X$ e $Y$ ) sobre a influência das Hélices Holísticas de Inovação na Ecoinovação, bem como da Ecoinovação nas Práticas Ambientais, Produção Mais Limpa, Ações Sociais, Desenvolvimento Regional, Cidades Inteligentes e Desenvolvimento Sustentável.

Método: O método utilizado foi uma pesquisa descritiva, quantita tiva, aplicada a 1.032 indivíduos residentes no Brasil e em Portugal, ana lisa da pormeio da Modela gem de Equações Estrutura is.

Originalidade/Relevância: Holistic Helixes of Innovation, Eco-innovation, Environmental Practices, Cleaner Production, Social Actions, Regional Development, Smart Cities and Sustainable Development.

Resultados: As Hélices holísticas de inovação influenciam fortemente a ecoinovação. Essa constatação pode contribuir para a promoção de políticas públicas de incentivo à integração en tre os stakeholders das hélices holísticas de inovação, como universidades, governo, indústrias, parques tecnológicos, spin-offs, incubadoras, startup, equipes de consultoria, orga nizações não governamentais, a cionistas, fornecedores e clientes. O estudo também mostra a influência positiva da ecoinovação nas práticas a mbientais, produção mais limpa, ações sociais, cidades inteligentes, desenvolvimento sustentável, com ênfase no desenvolvimento regional.

Contribuições teóricas/metodológicas: Os preceitos da ecoinovação são fundamentais para desenca dear influências positiva nos a spectos socioa mbientais, nas cidades inteligentes e no desenvolvimento regional e sustentável. Nesse sentido, organizações e governos podem contribuir com a sociedade, com maior eficiência, a locando recursos em projetos que desenvolvam inovações socioa mbientais.

Contribuições sociais/para a gestão: Pode-se observar o efeito moderador dos países (Brasil e Portugal), destacando que a relação entre Ecoinovação e Smart Cities é elevada em a mbos os países, mas há diferenças intensas na intensidade das relações.

Palavras-chave: Hélices holísticas de inovação. Ecoinovação. Desenvolvimento sustentável. Brasil. Portugal.

\section{ANTECEDENTES Y CONSECUENCIAS DE LA ECOINNOVACIÓN PARA LA SOSTENIBILIDAD: PERCEPCIONES DE GENERACIONES EN BRASIL Y PORTUGAL}

Objetivo: Este estudio tiene como objetivo analizar la percepción de generaciones (Baby boomers, X e Y) sobre la influencia de los Propulsores de la Innovación Holística en la Ecoinnovación, así como la Ecoinnovación en Prácticas Ambientales, Producción más Limpia, Acciones Sociales, Desarrollo Regional, Ciudades Inteligentes y Desarrollo Sostenible. Método: El método utilizado fue una investigación descriptiva, cuantitativa, aplicada a 1.032 personas residentes en Brasil y Portugal, analizada mediante Modelado de Ecuaciones Estructurales.

Originalidad/Relevancia: Hélice holística de innovación, ecoinnovación, prácticas ambientales, producción más limpia, acciones sociales, desarrollo regional, ciudades inteligentes y desarrollo sostenible.

Resultados: Las hélices de innovación holística influyen fuertemente en la ecoinnovación. Este hallazgo puede contribuir a la promoción de políticas públicas para fomentar la integración entre los actores de las hélices de la innovación holística, como universidades, gobierno, industrias, parques tecnológicos, spin-offs, incubadoras, startups, equipos de consultoría, organizaciones no gubernamentales, accionistas, proveedores. y clientes. El estudio también muestra la influencia positiva de la ecoinnovación en las prácticas ambientales, producción más limpia, acciones sociales, ciudades inteligentes, desarrollo sostenible, con énfasis en el desarrollo regional.

Contribuciones teóricas/metodológicas: Los preceptos de la ecoinnovación son fundamentales para desencadenar influencias positivas en los aspectos sociales y ambientales, en las ciudades inteligentes y en el desarrollo regional y sostenible. En este sentido, las organizaciones y los gobiernos pueden contribuir a la sociedad, con mayor eficiencia, destinando recursos a proyectos que desarrollen innovaciones sociales y ambientales.

Contribuciones sociales/gerenciales: Se puede observar el efecto moderador de países (Brasil y Portugal), notando que la relación entre Ecoinnovación y Smart Cities es alta en ambos países, pero existen intensas diferencias en la intensidad de la relaciones.

Palabras clave: Hélices de innovación holística. Ecoinnovación. Desenvolvimiento sustentable. Brasil. Portugal. 


\section{Introduction}

Organizations of different sizes and segments, as well as society, have been negatively impacting the environment, which compromises the availability of natural resources for future generations. Environmental problems require new innovative solutions (Brem and Radziwon, 2017). However, in the development of innovation, it is necessary to incorporate environmental sustainability, to become an eco-innovation, that is, an innovation that aims at environmental sustainability.

Innovation is a source of competitive advantage for organizations, which is triggered by new products, processes, and services, and can be tied to environmental sustainability to minimize the impact on the environment. The global environmental crisis, including the lack of resources, environmental degradation, and pollution, has pushed countries all over the world to pay greater attention to sustainable development (Cai and $\mathrm{Li}, 2018$ ).

In this context, the multiple helixes of innovation emerge, which encompass the scope of government, companies, universities, suppliers, and clients, who suffer from normative, coercive and social pressures that are important for environmental preservation and natural resources. However, literature on the collaboration of the multiple helixes of innovation related to eco-innovation still leaves a research gap, as according to Yang et al. (2012), placing environmental issues on innovation helixes will expand the number of actors involved, and according to Guerrero and Urbano (2017), point out that in emerging economies, the benefits of the helixes of innovation are still unpredictable, which requires studies to better understand the influence of these agents on innovations.

According to Vieira and Radonjič (2020), there is a general lack of direct reference to the term eco-innovation, since the sustainability reports of European companies (Dow Jones Sustainability Index) show that companies have released information on different types of eco-innovation, although they did not explicitly refer to them as eco-innovations. However, according to Barbieri and Santos (2020), eco-innovative businesses are prominent elements in the development of sustainable production and consumption systems in organizations of all sizes, especially for small and medium-sized companies, where one of the main challenges is to direct eco-innovation strategies for the purposes of your business model. Therefore, eco-innovation is classified as a methodology used in the industrial process, which aims to optimize materials and natural resources, aiming at the efficiency of the production process, the reduction of industrial waste, consequently the improvement of organizational performance and the decrease environmental impact (Severo et al., 2018; García-Granero et al., 2018).

Coherently, environmental practices and cleaner production methodology can be used to segregate waste generated correctly and reduce the consumption of natural resources. For Ikram et al. (2019), the adoption of an environmental management system can be an effective tool for organizations to address economic, social and environmental issues, in addition to being a viable means of developing business objectives and improving social responsibility activities (Ikram et al., 2019), as well as investments in reducing emissions and renewable energy consumption, simultaneously improve environmental sustainability practices (Ikram et al., 2020a). In this scenario, according to Ikram et al. (2020b), the environmental certification also contributes effectively to economic development in developed and developing countries. Therefore, organizations that make use of environmental practices will be contributing to the preservation of the environment and the quality of life of society. 
Although researchers and practitioners focus their attention on the economic and environmental dimension of sustainability, less attention is paid to the social dimension of sustainability, particularly in developing countries (Kumar and Anbanandam, 2019). Social actions with a focus on innovation drive organizational change, stimulate holistic strategic management, approach to sustainability challenges (Roome, 2011).

According to Machado Jr. et al. (2018) and Guimarães et al. (2020), cities with a set of superior economic, social and environmental indicators have the potential to present better living conditions for their inhabitants. However, the knowledge and framework for data use for smart cities remain relatively unknown (Lim et al., 2018). Another important aspect is the view of consumers on the environmental practices of companies (Severo et al., 2018), as well as the perspective of environmental awareness of individuals, on the importance of preserving these resources and using sustainable environmental practices (Fraj and Martinez, 2007; Severo et al., 2019).

To research the perspectives of individuals in society, it was divided into three distinct groups, considering the respondents' year of birth as a criterion, for both groups were formed based on the studies of Strauss and Howe (1991) and Severo et al. (2018): i) Baby Boomers Generation those born before 1965; ii) Generation X those born between the years 1965 to 1981; and, iii) generation Y those born after 1981. The generations (Baby Boomers, Generation X, Generation Y) have different behaviors and characteristics (Akhras, 2015; Severo et al., 2018). It is noteworthy that in the studies by Strauss and Howe (1991), Zopiaris et al. (2012), Zahari and Esa (2016), Lissitsa and Kol (2016) and Severo et al. $(2018$; 2019) indicate that the Baby Boomers generation has more conservative and optimistic behaviors, while Generation X seeks professional stability, and at the other extreme Generation Y has a preference for challenges, has great ability to take risks, and is highly creative, innovative and individualistic.

In the light of the above, this study aims to analyze the perception of generations (Baby boomers, X and Y) about the influence of the Holistic Helixes of Innovation (HHI) on Eco-innovation (EI), as well as Eco-innovation about Environmental Practices (EP), Cleaner Production (CP), Social Actions (SA), Regional Development (RD), Smart Cities (SC) and Sustainable Development (SD). The analysis occurred through the perception of 587 Brazilians and 445 Portuguese, measured through multivariate data analysis with the application of Structural Equation Modeling (SEM).

\section{Theoretical Background}

\subsection{Holistic helixes of innovation and eco-innovation}

In what concerns innovative helixes, Etzkowitz and Leydesdorff (1995) highlight the triple helix, in which innovation occurs at the intersection of three institutional spaces, companies, government and educational institutions (Yoda and Kuwashima, 2020). If innovation is the engine of economies, the partnerships in the triple helix model of innovation are the fuel that makes this engine work (Mascarenhas et al., 2020). For Yu et al. (2020), innovation is an important engine for the progress of science and technology.

For Sato (2017), an in-depth investigation is needed of how successful cases of innovation were achieved only after an attractive environment was created, primarily through combined efforts of interaction between industry (business), university, and government. According to $\mathrm{Yu}$ et al. (2020), it is imperative to promote the sustainable development of science and technology service intermediaries, as well as external institutions that support innovation activities.

According to this triad, each strand relates to the other two, developing an overlap of communications, networks, and organizations (Dudin et al., 2015). However, for 
Carayannis and Campbell (2009) there is a fourth helix, which combines from the perspective of an audience based on media and culture, resulting in an ecosystem of knowledge and emerging innovation, well configured for the knowledge economy and society. According to Carayannis et al. (2017), the fifth helix supports the formation of a win-win situation between ecology, knowledge, and innovation, creating synergies between economy, society, and democracy, which is the good basis for the sustainable development of the territories.

In this scenario, these interactions between the multiple helixes of innovation, in turn, are the key to fostering innovation and the economic development of countries and organizations (Etzkowitz and Leydesd orff, 2000; Razak and White, 2015; Li et al., 2018).

However, innovating with environmental sustainability into account may be the new frontier of organizational competitiveness (Severo et al., 2018). According to this, eco-innovation can improve a company's environmental performance and, through environmental performance, have a positive impact on its economic performance (Cai and Li, 2018; You et al., 2019; Geng et al., 2020). Bringing environmental concerns into focus of innovation processes will in several cases also expand the numbers of actors involved (Yang et al., 2012). The multiple helixes of innovation can foster eco-innovation (Carayannis and Campbell, 2010; Gouvea et al., 2013).

\subsection{Eco-innovation, environmental practices and cleaner production}

In recent years, the search for innovative pathways towards sustainability has been brought to the forefront of international agenda settings (Severo and Guimarães, 2015; Colombo et al., 2019). According to Kanda et al. (2018), García-Granero et al. (2018) and Lin et al. (2020), eco-innovation is an approach to environmental sustainability. For Chen et al. (2017), an eco-innovation has become a core engine for long-term stable economic development, as well as a fundamental way to ease the tension between economic growth and environmental resources management.

Eco-innovation is a complex process that involves product, process, organizational and marketing dimensions, each with its own determinants, characteristics and contributions to environmental business performance (García-Granero et al. 2020).

In this context, in recent years, the theme of environmental practices, through ecoinnovation, has received increasing attention in academic research (Chen et al., 2017; Cai and Li, 2018; Hojnik et al., 2018; Hojnik and Ruzzier, 2016; Lin et al. 2020; Wang et al., 2020). According to Chen et al. (2017), in this new era of ecological civilization, ecoinnovation has a high and distinctive value for contemporary organizations. Hojnik et al. (2018) emphasize that eco-innovation adoption is on the rise, both by businesses and by consumers. At the industrial level, the development of eco-innovation is a mechanism to achieve sustainability (López and Montalvo, 2015), reduction of carbon emissions (Wang et al., 2020), and for the consumer, eco-innovation is a way of expressing conscious consumption (Severo et al., 2018).

At the global level, eco-innovation aims to use environmental practices, as well as designing a new system integrating the dimensions of sustainable development, adding the environment, social issues, technology and stakeholders (Pialot and Millet, 2018). However, Dieste et al. (2020) highlight that the impact of environmental practices on the environment is not yet effectively clarified. However, small and large companies use different resource allocation patterns to benefit from the implementation of environmental management practices and environmental management systems (Wong et al., 2020), as well as ISO 14001 certification (Ikram et al., 2020b).

Environmental practices are therefore aimed at reducing the use of natural resources such as materials, energy, water and land, as well as reducing the release of 
harmful substances through the introduction of a new or improved product/service, process, (Cheng and Shiu, 2012), or market programs (Chen et al., 2017), as well as the use of cleaner production methodology in the industrial process (Zhang et al., 2014; Pinto et al. et al., 2018; Severo et al., 2018; De Guimarães et al., 2019; Dong et al., 2019).

The cleaner production is an environmental methodology, which was created by the United Nations Industrial Development Organization, which is a specialized agency of the United Nations, which promotes industrial development for poverty reduction through an inclusive globalization and environmental sustainability (De Guimarães et al., 2019).

The 2017 International Workshop on Advances in Cleaner Production held in São Paulo, Brazil, in 2017, promoted an assisted discussion workshop directed by Donald Huisingh. The workshop focused on the role of the Advances in Cleaner Production Network to meet the United Nations Sustainable Development Goals (Giannetti et al., 2018). Cleaner production is a lively concept in which new procedures and technologies constantly emerge introducing methods and practices to prevent damages to the environment (Giannetti et al., 2020).

For, according to Cong and Shi (2019), cleaner production is a key concept of industrial sustainable development as well as research hotspot; as well as the continuous application of an integrated environmental preventive strategy that stresses the importance of environment and human beings (Dong et al., 2019).

\subsection{Eco-innovation and social actions}

The eco-innovation associated with social actions is still a recent topic in the scientific literature. In general, social responsibility is related to social actions towards employees and society, as well as philanthropy, reputation and organizational image (Jamali et al., 2015, Voegtlin and Greenwood, 2016, Gold et al., 2018, López-González et al., 2019). According to Yuan et al. (2018), still, there is disquiet on how these companies go about undertaking community development initiatives spawning various forms of criticisms regarding negative side-effects of corporate social action.

In this context, eco-innovation implementation is positioned as a target for organizations to be more sustainable in order to reduce negative externalities and reach governments 'green requirements and consumers' demands (García-Granero et al., 2018). For Hojnik and Ruzzier (2016) regulations and market, attraction factors are the most critical drivers of Eco-innovation in companies.

According to Halkos and Skouloudis (2018), recent and drastic socioeconomic and political changes, inefficiencies in the public sector, limited resources due to macroeconomic instability (economic recession 2008/2009), makes companies more actively involved in the mitigation of environmental and social pressures, problems beyond the mere management of externalities, leading to a creation of value for the common benefit. For Kumar and Anbanandam (2019), a sustainable business organization needs to consider the importance of economic, environmental, and social sustainability.

Tamvada (2020) highlights that a vast literature focuses on the nature, role, and dynamics of corporate social responsibility, however recently, an emerging part of literature is examining the need to regulate corporate social responsibility. As new customers become more informed and responsible about the environment, companies need to act responsibly to attract responsible customers (Akbari et al. 2019).

According to Del Baldo (2019), the improvement of a socially responsible commitment, with corporate social responsibility practices and the creation of a public benefit, as well as improvements in accountability, transparency, and stakeholder 
engagement, optimize social actions. Social actions can act as a catalyst to deal with pressing social problems that, if properly managed, can be transformed into large-scale social opportunities (Rake and Grayson, 2009; Low and Siegel, 2019).

\subsection{Eco-innovation, regional development and smart cities}

Eco-innovation is an effective way to bring together new technologies, communication, and environmental sustainability. In this sense, Xavier et al. (2017) indicate that various business models have been proposed to help companies achieve a greater understanding of the dynamics of eco-innovation in order to facilitate the integration of sustainable processes by optimizing dynamic capabilities and capabilities. Therefore, for Bossle et al. (2016) it is important to include all actors in the process of transition to an economy that integrates ecological concepts into innovation and competitiveness strategies, which is the main function of the eco-innovation strategy.

Tamayo-Orbegozo et al. (2017) point out that eco-innovation attracts interest among companies, governments, and researchers as a means of achieving a higher degree of sustainable development. Therefore, eco-innovation contributes significantly to the development of the region in a sustainable way, since innovation can be directed towards sustainable development in order to preserve natural resources for future generations (Severo et al., 2018).

According to Beretta (2018), it is necessary to know whether projects with environmental objectives also produce socially beneficial results, with special reference to the issue of social inclusion. Also, according to the author, The European Union is institutionalizing eco-innovation and smart cities, aiming at improving the quality of life of citizens. In this sense, cities worldwide are attempting to transform themselves into smart cities (Lim et al., 2018).

In recent years, smart city has attracted increasing attention from both academia and industry due to a mix of urbanization, informatization, and globalization (Zheng et al., 2020). In this scenario, smart cities are projects in which a certain urban space uses information-aware communication and information technologies, urban management and social action driven by data, and Internet of Things (IoT) (Caragliu et al., 2011; Fei et al., 2016; Sharma et al., 2020), reference to the issue of social inclusion (Beretta, 2018). In this sense, smart cities present themselves as a viable solution to aggregate public resources, human capital, social capital and information, and communication technologies, to promote sustainable development (De Guimarães et al., 2020).

According to Beretta (2018), urban populations are increasing, as are the consumption of energy, transport and water, and the construction of buildings and public spaces. In this sense, smart cities represent the context in which eco-innovation is highly needed. For this, it is fundamental to find intelligent solutions, that is, highly efficient and sustainable, generating economic prosperity and social welfare.

In this scenario, the evaluation of balanced regional development should consider not only the economic and ecological benefits but also regional differences (Shu and Xiong, 2018). Para Chen et al. (2019), the degree of openness, urbanization, ind ustrial structure, and technological innovation play an active role in promoting regional green sustainable development. It should be stressed that the sharing of common resources, with the objective of establishing urban and regional innovation ecosystems, requires sustainable partnerships and cooperation strategies among the different stakeholders, which aim at sustainable development. Such a development is able to meet the needs of today's generations without compromising the supply capacity of future generations. 


\subsection{Eco-innovation and sustainable development}

Eco-innovation is based on a definition established by the European Commission (2018) and the assimilation, production, and exploitation of new services and processes whose main objective is to prevent or reduce the negative impacts of the use of different resources, and is based on this, that eco-innovation emerges as an alternative that integrates an existing gap between the market and research, since it is through the development of new products, processes, services and also new forms of management and business methods that are articulated that aim to protect the environment and meet environmental objectives, and drive economic growth.

To contribute to the discussion, Carrillo-Hermosilla et al. (2009) emphasize that the concept of eco-innovation considers the impacts of the industry on the environment, based on a need for more sustainable development, of which there is an interdependence between the environment and the economy. In this context, Aldieri et al. (2019) analyzed the impact of eco-innovation in contexts with differentiated economic structures and public policy mediations (USA, Japan, and Europe), and concluded that there is a relationship between the institutional framework, public policies and the effects of ecoinnovation in fostering sustainable development. In this sense, the intermediaries (universities, incubators, organizations and public service) that supports the production of eco-innovations assumes roles guided by learning, aggregation, awareness, and interaction among themselves (Kanda et al., 2018).

According to Cancino et al. (2018) there is a need to manage technological innovations for sustainable growth from a systematic perspective. Tamayo-Orbegozo et al. (2017) points out that eco-innovation is an emerging issue among companies, universities and governments, as this is an efficient way to achieve a higher degree of sustainable development. Sustainable innovations can influence sustainable development by creating a new generation of sustainable products, services and technologies capable of stimulating the world economy and regional development (Gouvea et al., 2013; De Guimarães et al., 2018).

Thus, eco-innovation is a tool that demonstrates the evolution of the environmental behavior of organizations, aiming at reducing environmental impacts, improving environmental performance and providing sustainable development and becoming a competitive advantage alternative (Peiró-Signes and Segarra-Oña, 2018; Kiefer et al., 2018; Salim, 2019).

The United Nations 2030 Agenda for Sustainable Development is comprehensive, and its contributions aim at participation, partnerships, education, sustainable living and global citizenship (Shulla et al., 2020). Coherently, the United Nations (UN) presented 17 Sustainable Development Goals (SDGs), which can be used by different nations and companies. The research by Martins et al. (2020) points out that Brazil has been carrying out some relevant actions, both sporadic and planned, with significant opportunities for improvement, where the most cited contributions are those related to increased productivity and technological modernization, which contributes to the insertion of young people in the market improving resource efficiency and minimizing environmental degradation.

For Zhao et al. (2020), the efforts of curbing air pollution and improving air quality are especially valuable for sustainable development. In this scenario, sustainable development aims to meet the needs of current generations, without compromising the availability of natural resources for future generations, as well as the availability of energy and food (Severo et al., 2018). 
In this context, Table 1 presents a summary of the concept used in the researched constructs, which also supported the research hypotheses, by comparing the researched studies, the gaps and contributions of this research.

Table 1

Constructs and definitions, gaps and contributions of this research

\begin{tabular}{l|l}
\hline Construct & Definitions \\
\hline $\begin{array}{l}\text { Holistic Helixes of } \\
\text { Innovation (HHI) }\end{array}$ & $\begin{array}{l}\text { The Holistic Helixes of Innovation (HHI) is characterized by interactions } \\
\text { between government, industry, business, public and civil society, the natura }\end{array}$
\end{tabular}
environment, the access to knowledge/technology, sources of funding and government subsidies, which can impact the performance of companies different sizes, knowledge management, the development of innovative projects, climate change and the scientific-educational community. Those theoretical a ssumptions are based on Etzkowitz and Leydesdorff (1995), Etzkowitz and Leydesdorff (2000), Carayannis and Ca mpbell (2009), Razak and White (2015), Dudin et al. (2015), Sato (2017), Carayannis et al. (2017), Guerrero and Urbano (2017), Brem and Radziwon (2017) and Li et al. (2018), Mascarenhas et al. (2020), Yu et al. (2020), and Yoda and Kuwashima (2020).

Eco-innovation (EI) $\quad$ The Eco-innovation (EI) is an innovation aimed at environmental sustainability, it is important for the development of production systems, sustainable consumption in organizations of all sizes, drives and environmental resources management, organizational performance, issues social, technology and stakeholders, as well as integrating ecological concepts in innovation and competitiveness strategies. Those theoretical assumptions are based on López and Montalvo (2015), Bossle et al. (2016), Chen et al. (2017), Severo et al. (2018), Pialot and Millet (2018), Kanda et al. (2018), García-Granero et al. (2018), Cai and Li (2018), Vieira and Radonjič (2020), Barbieri and Santos (2020), Wang et al. (2020), and García-Granero et al. (2020).

\begin{tabular}{l|l}
\hline Environmental & The Environmental Practices (EP) aim at the correct segregation and disposal of
\end{tabular} \begin{tabular}{l|l} 
Practices (EP) & waste, reducing the use of natural resources and polluting emissions, such as
\end{tabular} materials, energy, water and land, the use of renewable energies, is an effective tool for organisations to address economic, social and environmental issues. Those theoretical assumptions are ba sed on Cheng and Shiu (2012), Severo and Guimarães (2015), Ikram et al. (2019), Ikram et al. (2020a), Ikram et al. (2020b), and Wong et al. (2020).

\begin{tabular}{lll}
\hline Cleaner Production & $\mathrm{CP}$ is a methodology used in industrial processes, which seeks to optimize the
\end{tabular} (CP) $\quad$ use of materials and natural resources and to reduce industrial waste, prevents pollution, is a key concept of industrial sustainable development as well as research hotspot, an integrated environmental preventive strategy that stresses the importance of environment and human beings. Those theoretical assumptions are based on Zhang et al. (2014), Pinto et al. et al. (2018), Severo et al. (2018), Giannetti et al. (2018), De Guimarães et al. (2019), Dong et al. (2019), and Giannetti et al. (2020).

Social Actions (SA) $\quad$ SA is related to social actions towards employees and society, promoted by a collaborative system by private and public companies, for profit, non-profit and civil organizations, institutions, BCs and among others, as well as philanthropy, reputation and organizationalimage. Those theoretical assumptions are based on Jamaliet al. (2015), Voegtlin and Greenwood (2016), Gold et al. (2018), López-González et al. (2019), Del Baldo (2019), Low and Siegel (2019), and Tamvada (2020).

\begin{tabular}{|c|c|}
\hline $\begin{array}{l}\text { Regional } \\
\text { Development (RD) }\end{array}$ & $\begin{array}{l}\text { The degree of openness, urbanization, industrial structure and technological } \\
\text { innovation play an active role in promoting regional sustainable development. } \\
\text { Those theoretical assumptions are based on Liu and Huang (2018), Bossle et al. } \\
\text { (2016), Shu and Xiong (2018), and Chen et al. (2019), }\end{array}$ \\
\hline Smart Cities (SC) & $\begin{array}{l}\text { Uses informationalcommunication and information technologies, Internet of } \\
\text { Things (IoT), urban management and socialaction guided by data, aiming to } \\
\text { improve the quality of life of citizens. Those theoretical a ssumptions are based }\end{array}$ \\
\hline
\end{tabular}




\begin{tabular}{l|l}
\hline & $\begin{array}{l}\text { on Cara gliu et al. (2011), Fei et al. (2016), Beretta (2018), Sharma et al. (2020), } \\
\text { Zheng et al. (2020), and De Guimarães et al. (2020). }\end{array}$ \\
\hline Sustainable & $\begin{array}{l}\text { SD is the development that is concerned with naturalresou rces, so that future } \\
\text { generations have their needs met. They aim at participation, partnerships, } \\
\text { education, insertion of young people in the labor market, sustainable living, } \\
\text { clean air, resource efficiency, minimizing environmental degra dation and } \\
\text { promoting global citizenship. Those theoretical a ssumptions are ba sed on } \\
\text { Severo et al. (2018), Beretta (2018), Zhao et al. (2020), Martins et al. (2020), } \\
\text { and Shulla et al. (2020). }\end{array}$ \\
\hline
\end{tabular}

\section{Method}

\subsection{Research hypotheses}

Based on the studies presented in the Theoretical background section, important concepts and dependency relationships between the constructs were identified: Holistic Helixes of Innovation, Eco-innovation, Environmental Practices, Cleaner Production, Social Actions, Regional Development, Smart Cities and Sustainable Development. Based on the literature consulted the Theoretical Model (Fig. 1) was developed, consisting of seven hypotheses, which expresses the Theoretical Framework of analysis of the data of the research, considering the relations of influences between the constructs. The research hypotheses are presented below:

H1: The Holistic Helixes of Innovation are positively related to Eco-innovation.

H2: Eco-innovation is positively related to Environmental Practices.

H3: Eco-innovation is positively related to Cleaner Production.

H4: Eco-innovation is positively related to Social Actions.

H5: Eco-innovation is positively related to Regional Development.

H6: Eco-innovation is positively related to Smart Cities.

H 7: Eco-innovation is positively related to Sustainable Development.

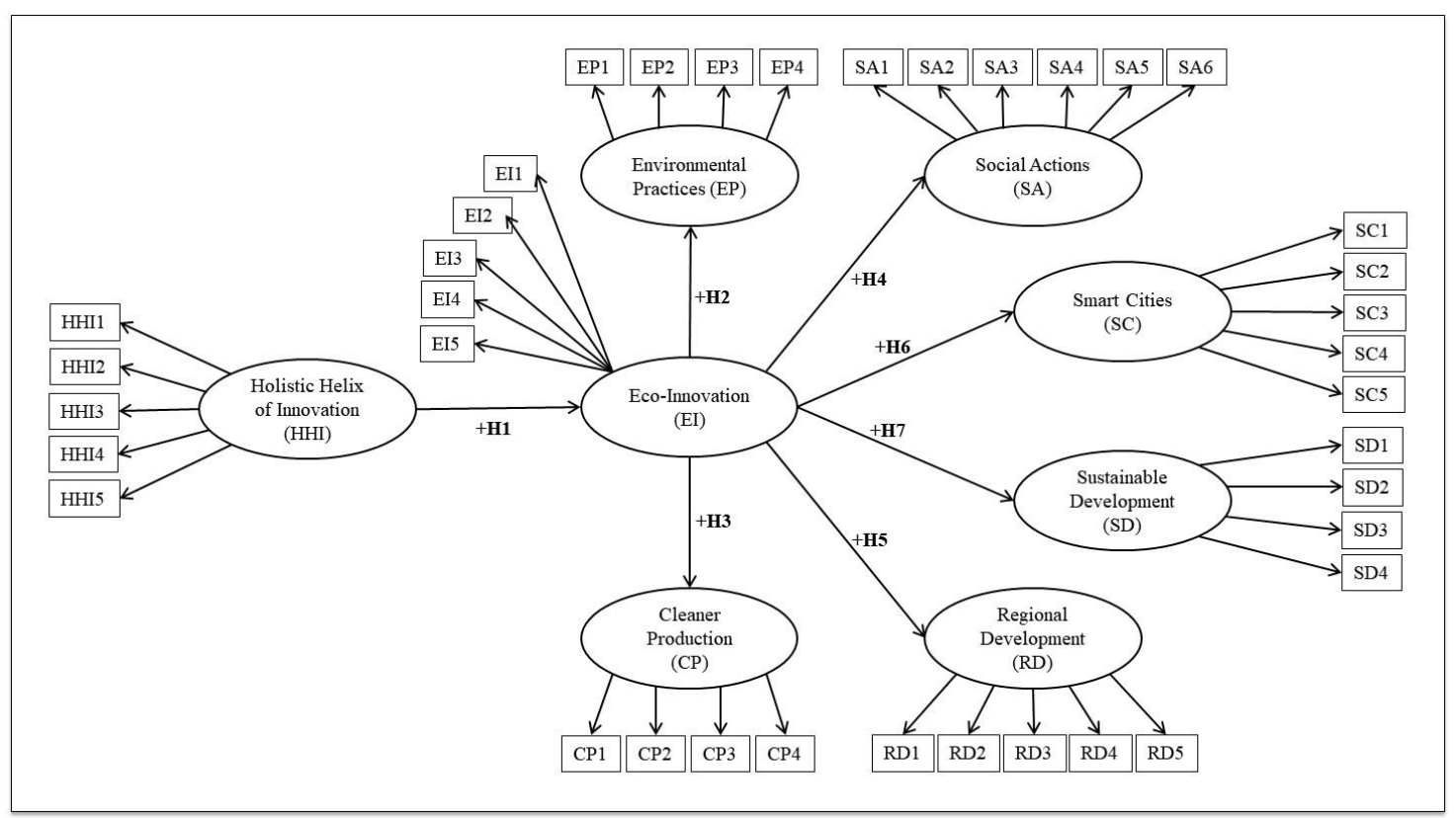

Fig. 1. Theoretical Model - Research Hypothesis Framework

As an addition to the research, the moderating effect of the Generations (Baby Boomers, Generation X, Generation Y) was evaluated on the constructs, assuming that there must be different perceptions of the respondents, depending on the Generation of each group, which should interfere in the means responses in each construct.

Another variable tested was the moderating effect of the country in which the respondent resides (Brazil or Portugal), considering that the two countries are in different 
stages of economic, environmental and social development, although these countries share the same language and that Brazil has been primarily colonized by Portugal.

\subsection{Data collect and data analysis}

The quantitative and descriptive research was carried out on individuals residing in Brazil and Portugal, through an applied survey collected with Snowball technique, in which initially the researchers sent the electronic questionnaire (Google Forms) to the contacts of social networks, as they replicated the research to other people, thus obtaining 1085 answers. Data collection was carried out from November 2019 to March 2020.

In order to characterize the respondents' profile, the following questions were asked: i) Respondent's age: respondents were classified based on the studies of Strauss and Howe (1991) about the different generations, dividing those born before 1965 as Baby boomers, a generation X born between 1965 and 1981, and generation Y born after 1981; ii) Gender: female, male or other; iii) Degree of Schooling; iv) Work and position in the company.

The questionnaire (Table 2) was developed based on the studies:

a) Holistic Helixes of Innovation (HHI): ad apted from the studies of Etzkowitz and Leydesdorff (1995), Etzkowitz and Leydesdorff (2000), Gouvea et al. (2013), Grundel and Dahlström (2016), Guerrero and Urbano (2017), and Chen et al. (2018);

b) Eco-innovation (EI): based on the study by Severo et al. (2018);

c) Environmental Practices (EP): adapted from studies by Severo et al. (2018), García-Granero et al. (2018) and Pinto et al. (2018);

d) Social Actions (SA): adapted from the studies of Voegtlin and Greenwood (2016), Tamayo-Orbegozo et al. (2017), Loosemore et al. (2018), Halkos and Skouloudis (2018);

e) Regional Development (RD): adapted from the studies of Liu and Huang (2018) and Bossle et al. (2016);

f) Smart Cities (SC): adapted from Caragliu et al. (2011) and Fei et al. (2016), Beretta (2018), and Nilssen (2019);

g) Sustainable Development (SD): adapted from studies by Severo et al. (2018) and Beretta (2018).

The questionnaire consists of affirmations (Table 2) in which the respondent chose in a 5-Point Likert scale (from totally disagree to totally agree) the answer that best expresses the opinion on the subject questioned.

Table 2

Observable variables and constructs

Observable Variables

Holistic Helixes of Innovation (HHI)

HHI1) I believe that interactions between government, universities, technology parks, business incubators, spin-offs, startup companies, clients and suppliers characterize the Holistic Helixes of Innovation and promote Eco-innovation.

HHI2) I observe in the regional context the positive impacts caused by the Holistic Helixes of Innovation.

HHI3) I consider the Holistic Helixes of Innovation to be the key to the development of new environmentally correct products, processes, and services.

HHI4) I consider that the relationship of the Holistic Helixes of Innovation is a decisive factorfor economic, social and environmentaldevelopment.

HHI5) Government policies are fundamental for the interaction between the agents of the Holistic Helixes of Innovation.

Eco-Innovation (EI) 
EI1) Eco-innovation fosters a new perspective on the relationship between innovation and the environment.

EI2) Eco-innovation provides value to the business/product/service.

EI3) Eco-innovation encourages the use of Environmental Practices in companies.

EI4) Eco-innovation leads to reduced environmentalimpact.

EI5) Eco-innovation contributes to achieving long-term sustainability results.

Environmental Practices (EP)

EP1) EnvironmentalPractices reduce the use of natural resources, materials, energy, water, land and the release of harmfulsubstances.

EP2) The implementation of EnvironmentalPractices associated with Eco-innovation makes organizations more sustainable.

EP3) In my residence I carry out the separation of recyclable and electronic waste.

EP4) The use of EnvironmentalPractices influences my environmentalawareness.

Cleaner Production (CP)

CP1) I prefer to buy products or services from companies that seek to reduce the consumption of raw material, water and energy in their processes.

CP2) Whenever possible, I try to acquire products and services from companies that work on improvements in the production process that reduce the generation of waste.

CP3) I think it is very important for companies to use new practices that target CP.

CP4) I believe that the use of CP methodologies positively broadens the company's image vis-à-vis the stakeholders.

\section{Social Actions (SA)}

SA1) The Social Actions developed by companies help people who are in social vulnerability.

SA2) The Social Actions developed by companies influence the reduction of poverty and social inequality.

SA3) The Social Actions developed by companies stimulate the commitment to the future of children.

SA4) The Social Actions of companies stimulate care with health, safety and working conditions.

SA5) The Social Actions of companies go beyond employees and society, aim at philanthropy, reputation, and organizationalimage.

SA6) Regiona1/global social problems influence my actions of social responsibility.

\section{Regional Development (RD)}

RD1) The new business models (Cooperatives, Business Networks, Associations, Individual MicroEntrepreneur, others) of companies promote Regional Development.

RD2) The economy that integrates ecological concepts into strategies of innovation and competitiveness promotes Regional Development.

RD3) The Regional Development caused new sources of income in the region.

RD4) Regional Development contributes to increased employment in the region.

RD5) I noted that Eco-innovation promotes Regional Development.

\section{Smart Cities (SC)}

SC1) The environmental actions of smart cities minimize en vironmentalimpacts.

SC2) I consider that smart cities use projects with data-driven communication and information technologies, with reference to the issue of social inclusion.

SC3) The social and environmentalactions of smart cities improve people's quality of life.

SC4) I believe that smart cities using Eco-innovation contribute to sustainability, generating economic prosperity and social well-being.

SC5) Eco-innovation in smart cities develops skills forcities to be innovative, improving urban qua lity of life.

\section{Sustainable Development (SD)}

SD1) My consumption of food/products/services is conscious of Sustainable Development.

SD2) I use collective vehicles (bus, train, subway, bicycles, others) aiming at Sustainable Development.

SD3) I buy green products thinking about Sustainable Development.

SD4) I use the natural resources (water, earth, sun, winds, others) aiming at Susta inable Development.

Likert Scale: 1 Totally Disagree; 2 Partially Disagree; 3 don't agree, don't disagree;

4 Partly Agree; 5 Totally Agree 
Data collection occurred by applying the questionnaire to residents in Brazil and Portugal, obtaining a non-probabilistic sample, collected for convenience, using the Snowball method, from the contacts of the researchers in the social networks (Facebook and LinkedIn). The collection of data through snowball sampling was based on the precepts of Snijders (1992), in which the researchers identified members of a specific population (participants from their social networks), who were asked to identify other members of the population, those so identified are asked to identify others, and so on. It is notew orthy that the researchers asked the respondents to share the online questionnaire (Google Forms) with their contacts on social networks, thus the data collection expanded rapidly among respondents from Brazil and Portugal.

Initially, a pre-test was done with 50 respondents, to evaluate the comprehension of the questions. Subsequently, the pretest responses were incorporated into the research sample. Data collection resulted in a total of 1085 forms answered. After data cleaning, there were 1032 valid cases, which is higher than recommended by Kline (2011) and Hair Jr. et al. (2014) that suggest for the use of SEM between 200 and 400 respondents and at least 10 responses foreach variable, in which the final sample resulted in 27.2 respondents per observed variable.

The final sample consists of 1032 valid cases, distributed in: i) place of the respondent: 587 from Brazil; 445 from Portugal; ii) Generation: 13.4\% Baby Boomers (Born before 1965); 28.5\% Generation X (Born in the period from 1966 to 1994); 58.1\% Generation Y (Born 1995); iii) Gender: 56.4\% female; $43.6 \%$ male; iii) Education: $58.8 \%$ are studying or have a degree; $19.3 \%$ are studying or have a specialization (Postgraduation); $12.1 \%$ are studying or have a master's degree, doctorate or postdoctoral degree; iv) $87.8 \%$ of the respondents are working in: $29.8 \%$ auxiliary / technical / analyst, 13.8 managers, $19.0 \%$ teachers and $37.5 \%$ other professional activities.

In Fig. 2 the methodological proced ures of the research are described, considering Data collect, Data Analysis and Hypothesis Testing. For the data analysis, the normality and reliability of the data were verified and later the Exploratory Factor Analysis (EFA) with Varimax Rotation, through the use of SPSS ${ }^{(v .21)}$ software.

The application of the Structural Equation Modeling (SEM) method used the precepts of Hair Jr. et al. (2014), was made with the assistance of AMOS® (v.21) software. To calculate the relationships between constructs, the SEM method based on covariance (CB-SEM) was used, since this method allows us to evaluate the effects of mediation and moderation, considering several groups and multi-group analysis. 


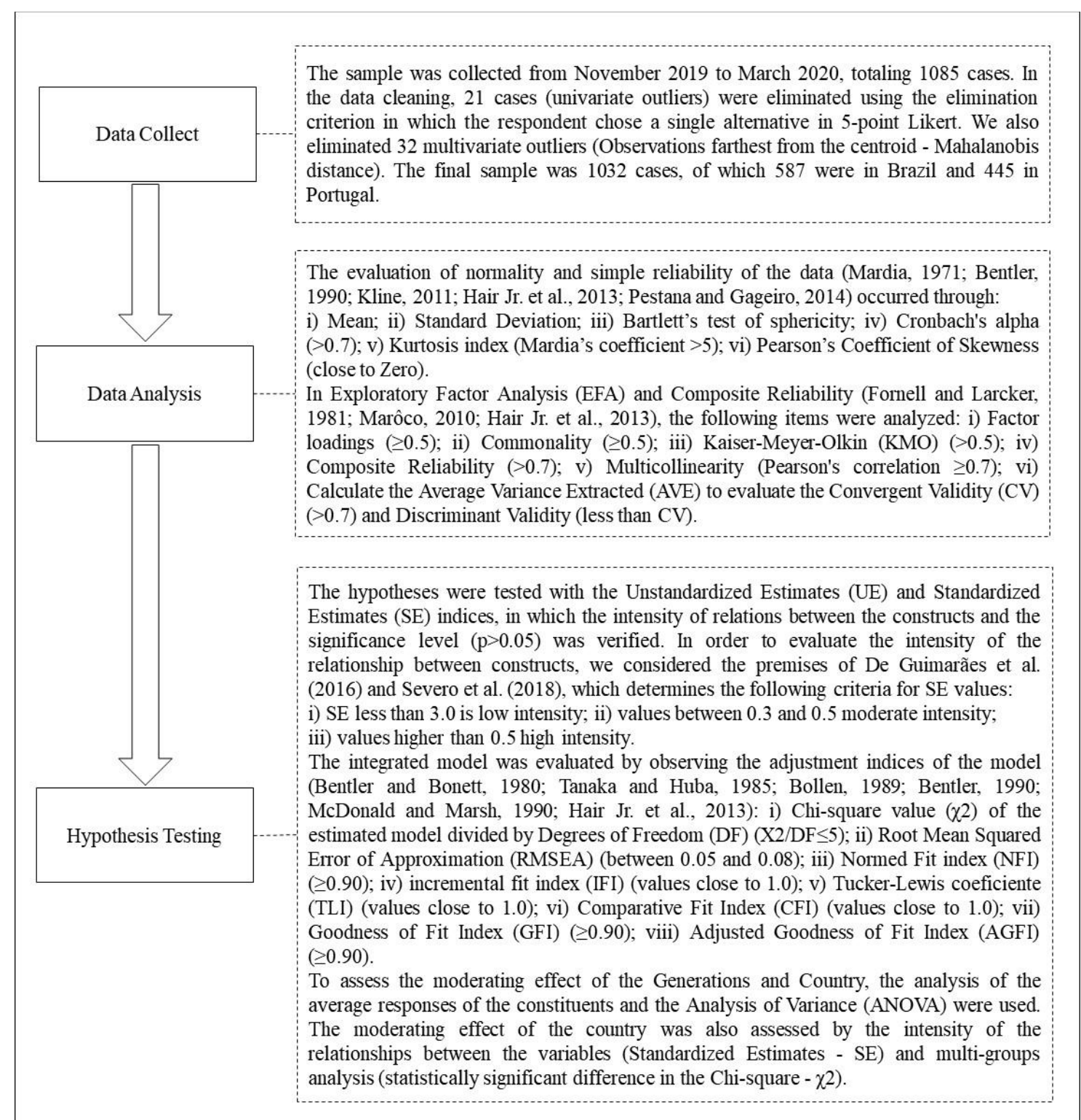

Fig. 2. Search method

\section{Results and Discussion}

After cleaning the data, Data Analysis and Hypothesis Testing procedures were performed (Fig. 1), which used multivariate data techniques, especially the evaluation of the measurement model (relationship between observable variables and construct formation) and the structural model (relationships between constructs).

The data collected through social networks influenced the high index of respondents of Generation Y (58.1\%). Most of the respondents are enrolled in higher education (Undergraduate $58.8 \%$ ) and $31.4 \%$ are studying or have postgraduate studies (master's, doctoral or postdoctoral). This profile of the respondents allows more assertive answers since the training contributes to the understanding of the affirmative (questionnaire) presented in the survey.

In the process of evaluating normality, the reliability of the data was measured by Bartlett's test of sphericity (Pestana and Gageiro, 2014), which presented significant values $(\mathrm{p}<0.001)$ in the constructs and in the set of all variables (Table 3 ) proving that the hypothesis of the data is not normal cannot be accepted, therefore, the data can have a 
normal distribution. This result was confirmed by the test of Kurtosis index (Mardia's coefficient <5) (Mardia, 1971; Bentler, 1990) and Pearson's Coefficient of Skewness (Kline, 2011; Hair Jr. et al., 2014).

Table 4 shows the Cronbach's alpha values, which were above the recommendations (>0.7) by Hair Jr. et al. (2014). The Mean and Standard Deviation values of the observable variables (Table 4) show that the respondents agree with the affirmative since the mean responses were higher than 3.2 and the mean standard deviation of the responses were close to 1 . The greater discrepancy between the respondents to be observed in variable EP3, with a Standard Deviation of 1.4495 and average of 3.785, even though Standard Deviation can still be considered low.

The validation of scale, observable variables and constructs occurred with the application of Exploratory Factor Analysis (EFA) and Composite Reliability, following the precepts of Fornell and Larcker (1981), Marôco (2010) and Hair Jr. et al. (2014). In the calculation of the EFA (Table 4), the principal components analysis was used, using the Varimax Rotation, which grouped the variables observable in the 8 constructs (Holistic Helixes of Innovation - HHI, Eco-innovation - EI, Environmental Practices EP, Cleaner Production - CP, Social Actions - SA, Regional Development - RD, Smart Cities - SC, Sustainable Development - SD) with cumulative $73.1 \%$ Variance of data from all observable variables. It is observed in Table 3 that the Variance Explained of each construct was superior to $62 \%$, which is higher than recommended (> 60\%) by Hair Jr. et al. (2014).

The values of Kaiser-Meyer-Olkin (KMO) (Table 3) are higher (>0.5), indicating the adequacy of the factorial analysis model, through the test of the general consistency of the data. Therefore, the research data present adequacy and feasibility for the application of EFA. Factorial loads and Commonality (Table 4) resulted in values higher than that recommended $(\geq 0.5)$. These results indicate that the observable variables contribute to the formation of the construct and are highly correlated with each other.

Table 3

Tests of KMO, Bartlett's Sphericity and Variance Explained

\begin{tabular}{lcccccccc} 
& HHI & EI & EP & CP & SA & RD & SC & SD \\
KMO & 0.729 & 0.811 & 0.714 & 0.798 & 0.821 & 0.822 & 0.875 & 0.682 \\
$\begin{array}{l}\text { Bartlett's Test } \\
\text { of Sphericity }\end{array}$ & $3640,2^{*}$ & $2175.1^{*}$ & $7870.9^{*}$ & $1934.5^{*}$ & $5909.6^{*}$ & $3048.5^{*}$ & $3503.9^{*}$ & $1548.9^{*}$ \\
$\begin{array}{l}\text { Variance } \\
\text { Explained }\end{array}$ & $67.9 \%$ & $62.7 \%$ & $85.0 \%$ & $70.9 \%$ & $74.2 \%$ & $68.9 \%$ & $74.5 \%$ & $62.5 \%$ \\
\hline
\end{tabular}

* Level of significance $(\mathrm{p}<0.001)$

The Composite Reliability of the set of all variables resulted in 0.991 , as well as the Composite Reliability of the contours (Table 4) were higher than the recommended values (>0.7) by Hair Jr. et al. (2014). Composite Reliability evaluates the degree of consistency between multiple measures of a variable, so the observable variables and the constructs have measurement consistency, which makes possible the application of EFA and Structural Equation Modeling (SEM).

Pearson's correlation analysis identified high correlations (greater than 0.8) between SA1 $\rightarrow$ SA6 (0.841), SA2 $\rightarrow$ SA6 (0.815), SA3 $\rightarrow$ SA6 (0.850) and SA4 $\rightarrow$ SA6 (0.844) indicating Multilevel variable SA6, in this sense, Hair Jr. et al. (2014) claim that the Multicollinearity occurs when any single independent variable is highly correlated with a set of other independent variables. In this research, it was decided to maintain the SA6 variable because it presents different concepts of the other variables and contributes to the theoretical explanation of the SA construct. 
The tests of normality, reliability (simple and composite), tests of variance and EFA validated the scale and the constructs. Therefore, the questionnaire was statistically validated through the framework developed by Etzkowitz and Leydesd orff (1995; 2000), Caragliu et al. (2011), Gouvea et al. (2013), Bossle et al. (2016), Grundel and Dahlström (2016), Fei et al. (2016), Voegtlin and Greenwood (2016), Guerrero and Urbano (2017), Tamayo-Orbegozo et al. (2017), Beretta (2018), Chen et al. (2018), García-Granero et al. (2018), Halkos and Skouloudis (2018), Liu and Huang (2018), Loosemore et al. (2018), Nilssen (2019), Pinto et al. (2018), and Severo et al. (2018). The results of the research, referring to the measurement model (observable variables), allow to affirm that the scale developed in this research presents feasibility to measure the composition of the constructs, in this sense, the questionnaire can be applied in other contexts.

Table 4

Exploratory factor analysis (Varimax Rotation) and data reliability

\begin{tabular}{|c|c|c|c|c|c|c|}
\hline & $\begin{array}{c}\text { Factorial } \\
\text { Loads } \\
\end{array}$ & Communality & Mean & $\begin{array}{l}\text { Standard } \\
\text { Deviation }\end{array}$ & $\begin{array}{c}\text { Cronbach's } \\
\text { Alpha } \\
\end{array}$ & $\begin{array}{l}\text { Composite } \\
\text { Reliability } \\
\end{array}$ \\
\hline \multicolumn{7}{|c|}{ Holistic Helixes of Innovation (HHI) } \\
\hline HHI1 & 0.718 & 0.652 & 3.901 & 0.9069 & \multirow{5}{*}{0.871} & \multirow{5}{*}{0.930} \\
\hline HHI2 & 0.710 & 0.661 & 3.343 & 0.9429 & & \\
\hline HHI3 & 0.759 & 0.738 & 4.023 & 0.7776 & & \\
\hline HHI4 & 0.682 & 0.704 & 3.965 & 0.8279 & & \\
\hline HHI5 & 0.888 & 0.928 & 3.953 & 0.7460 & & \\
\hline \multicolumn{7}{|c|}{ Eco-Innovation (EI) } \\
\hline EI1 & 0.673 & 0.627 & 4.244 & 0.9082 & \multirow{5}{*}{0.848} & \multirow{5}{*}{0.907} \\
\hline EI2 & 0.638 & 0.592 & 4.128 & 0.8603 & & \\
\hline EI3 & 0.592 & 0.565 & 4.134 & 0.8762 & & \\
\hline EI4 & 0.750 & 0.721 & 4.250 & 0.7714 & & \\
\hline EI5 & 0.681 & 0.670 & 4.244 & 0.7845 & & \\
\hline \multicolumn{7}{|c|}{ Environmental Practices (EP) } \\
\hline EP1 & 0.967 & 0.982 & 4.157 & 0.9792 & \multirow{4}{*}{0.923} & \multirow{4}{*}{0.974} \\
\hline EP2 & 0.965 & 0.977 & 4.145 & 0.9751 & & \\
\hline EP3 & 0.926 & 0.864 & 3.785 & 1.4495 & & \\
\hline EP4 & 0.690 & 0.655 & 4.209 & 0.9169 & & \\
\hline \multicolumn{7}{|c|}{ Cleaner Production (CP) } \\
\hline CP1 & 0.774 & 0.711 & 3.963 & 0.8701 & \multirow{4}{*}{0.861} & \multirow{4}{*}{0.918} \\
\hline CP2 & 0.776 & 0.696 & 4.084 & 0.8131 & & \\
\hline CP3 & 0.812 & 0.739 & 4.281 & 0.7657 & & \\
\hline CP4 & 0.763 & 0.719 & 4.216 & 0.7216 & & \\
\hline \multicolumn{7}{|c|}{ Social Actions (SA) } \\
\hline SA1 & 0.783 & 0.774 & 3.634 & 1.0118 & \multirow{6}{*}{0.926} & \multirow{6}{*}{0.961} \\
\hline SA2 & 0.824 & 0.755 & 3.250 & 1.1009 & & \\
\hline SA3 & 0.799 & 0.771 & 3.634 & 1.0678 & & \\
\hline SA4 & 0.846 & 0.782 & 3.715 & 1.0150 & & \\
\hline SA5 & 0.656 & 0.512 & 3.767 & 1.0311 & & \\
\hline SA6 & 0.921 & 0.955 & 3.581 & 0.9276 & & \\
\hline \multicolumn{7}{|c|}{ Regional Development (RD) } \\
\hline RD1 & 0.592 & 0.627 & 4.064 & 0.8156 & \multirow{5}{*}{0.887} & \multirow{5}{*}{0.931} \\
\hline RD2 & 0.636 & 0.664 & 3.977 & 0.8354 & & \\
\hline RD3 & 0.708 & 0.785 & 3.971 & 0.8592 & & \\
\hline RD4 & 0.663 & 0.730 & 4.151 & 0.8899 & & \\
\hline RD5 & 0.572 & 0.704 & 3.831 & 0.8361 & & \\
\hline \multicolumn{7}{|c|}{ Smart Cities (SC) } \\
\hline SC1 & 0.780 & 0.761 & 4.081 & 0.9054 & \multirow{3}{*}{0.913} & \multirow{3}{*}{0.951} \\
\hline $\mathrm{SC2}$ & 0.680 & 0.730 & 3.767 & 0.9176 & & \\
\hline SC3 & 0.742 & 0.809 & 3.977 & 0.8828 & & \\
\hline
\end{tabular}




\begin{tabular}{lcccccc} 
SC4 & 0.770 & 0.790 & 4.047 & 0.8482 & & \\
SC5 & 0.741 & 0.724 & 4.041 & 0.8242 & & \\
\hline Sustainable Development (SD) & & & & & \\
SD1 & 0.577 & 0.595 & 3.651 & 0.9050 & & \\
SD2 & 0.871 & 0.838 & 3.598 & 0.7730 & 0.785 & 0.875 \\
SD3 & 0.778 & 0.691 & 3.494 & 0.9619 & & \\
SD4 & 0.722 & 0.597 & 3.710 & 0.8909 & & \\
\hline
\end{tabular}

The high values of the Factorial Loads, Communality and AVE indicate that the constructs are consistent in their measurements and that there is an intense internal correlation between the observable variables in the construct formation. This expresses the importance of the elements that make up each construct, for example, to evaluate EI is fundamental you approach the issues that involve the guidelines for sustainable business, among which are: relation between innovation and environment; to add value to the business/product/service; encouraging the use of environmental practices; reduction of environmental impact; and, achieving long-term sustainability results.

The Average Variance Extracted (AVE) was used to evaluate the Discriminant Validity (DV) based on Corrected Correlations of the Confirmatory Factor Analysis model, obtained by calculation in the AMOS® software, which uses the CovarianceBased SEM (CB-SEM). For Forell and Larcker (1981) and Severo et al. (2018), the AVE is used to evaluate the explanatory power of the observable variables (indicator) on the construct, measuring how much of the total variance of each indicator is being used to compose the construct evaluation.

To evaluate the AVE, the Fornell-Larcker criterion (Fornell and Larcker, 1981; Henseler et al., 2014) was used, which expects that the values of the Convergent Validity (CV) should be higher than the quadratic correlation with any other latent variable (construct), represented by the DV values. It is observed in the calculation of AVE(Table 5) that all the constructs present higher CV than DV.

Table 5

Average Variance Extracted (AVE)

\begin{tabular}{|c|c|c|c|c|c|c|c|c|}
\hline Constructs & HHI & $\mathbf{E I}$ & EP & $\mathbf{C P}$ & $\mathbf{S A}$ & $\mathbf{R D}$ & SC & SD \\
\hline $\begin{array}{l}\text { Holistic Helixes of Innovation } \\
(\mathrm{HHI})\end{array}$ & $0.732^{\mathrm{a}}$ & & & & & & & \\
\hline Eco-innovation (EI) & $0.514^{\mathrm{b}}$ & $0.663^{\mathrm{a}}$ & & & & & & \\
\hline EnvironmentalPractices (EP) & $0.107^{\mathrm{b}}$ & $0.310^{\mathrm{b}}$ & $0.903^{\mathrm{a}}$ & & & & & \\
\hline Cleaner Production (CP) & $0.299^{\mathrm{b}}$ & $0.614^{\mathrm{b}}$ & $0.264^{\mathrm{b}}$ & $0.737^{\mathrm{a}}$ & & & & \\
\hline Social Actions (SA) & $0.180^{\mathrm{b}}$ & $0.412^{\mathrm{b}}$ & $0.213^{\mathrm{b}}$ & $0.231^{\mathrm{b}}$ & $0.808^{\mathrm{a}}$ & & & \\
\hline Regional Development (RD) & $0.420^{\mathrm{b}}$ & $0.604^{\mathrm{b}}$ & $0.350^{\mathrm{b}}$ & $0.445^{\mathrm{b}}$ & $0.575^{\mathrm{b}}$ & $0.732^{\mathrm{a}}$ & & \\
\hline Smart Cities (SC) & $0.395^{\mathrm{b}}$ & $0.641^{\mathrm{b}}$ & $0.133^{\mathrm{b}}$ & $0.468^{\mathrm{b}}$ & $0.469^{\mathrm{b}}$ & $0.724^{\mathrm{b}}$ & $0.795^{\mathrm{a}}$ & \\
\hline $\begin{array}{l}\text { Sustainable Development } \\
\text { (SD) }\end{array}$ & $0.072^{\mathrm{b}}$ & $0.293^{\mathrm{b}}$ & $0.159^{\mathrm{b}}$ & $0.455^{\mathrm{b}}$ & $0.267^{\mathrm{b}}$ & $0.329^{\mathrm{b}}$ & $0.325^{\mathrm{b}}$ & $0.651^{\mathrm{a}}$ \\
\hline
\end{tabular}

a Average Variance Extracted (AVE) - Convergent Validity (CV)

b Discriminant Validity (DV)

In the measurement of the AVE (Table 5), it was identified that there is a high correlation $(\mathrm{CV}=0.724)$ among the $\mathrm{SC} \leftarrow \rightarrow \mathrm{RD}$, indicating that the greater the use of the $\mathrm{SC}$ precepts, the greater the RD perception. This finding of the research corroborates with the studies of Beretta (2018), Caragliu et al. (2011), and Fei et al. (2016), which show that the SC's objective is to improve citizens' quality of life and socio-environmental development.

Fig. 3 presents the measurement model and the structural model, with SEM results. From the application of the SEM, to evaluate the influence relationships between 
the constructs, the hypothesis tests were carried out, which resulted in the values of Unstandardized Estimates (UE) and Standardized Estimates (SE) expressed in Table 6. The results of UE and SE were statistically significant $(\mathrm{p}<0.001)$. Based on the assumptions of De Guimarães et al. (2016) and Severo et al. (2018), the SE values of the relationships between $\mathrm{EI} \rightarrow \mathrm{EP}(\mathrm{H} 2)$ and $\mathrm{EI} \rightarrow \mathrm{SD}(\mathrm{H} 7)$ are of moderate intensity. The relationships between $\mathrm{HHI} \rightarrow \mathrm{EI}(\mathrm{H} 1), \mathrm{EI} \rightarrow \mathrm{CP}(\mathrm{H} 3), \mathrm{EI} \rightarrow \mathrm{SA}(\mathrm{H} 4), \mathrm{EI} \rightarrow \mathrm{RD}(\mathrm{H} 5)$ and $\mathrm{EI} \rightarrow \mathrm{SC}(\mathrm{H} 6)$ are considered high intensity. The survey results indicate that the hypotheses were supported.

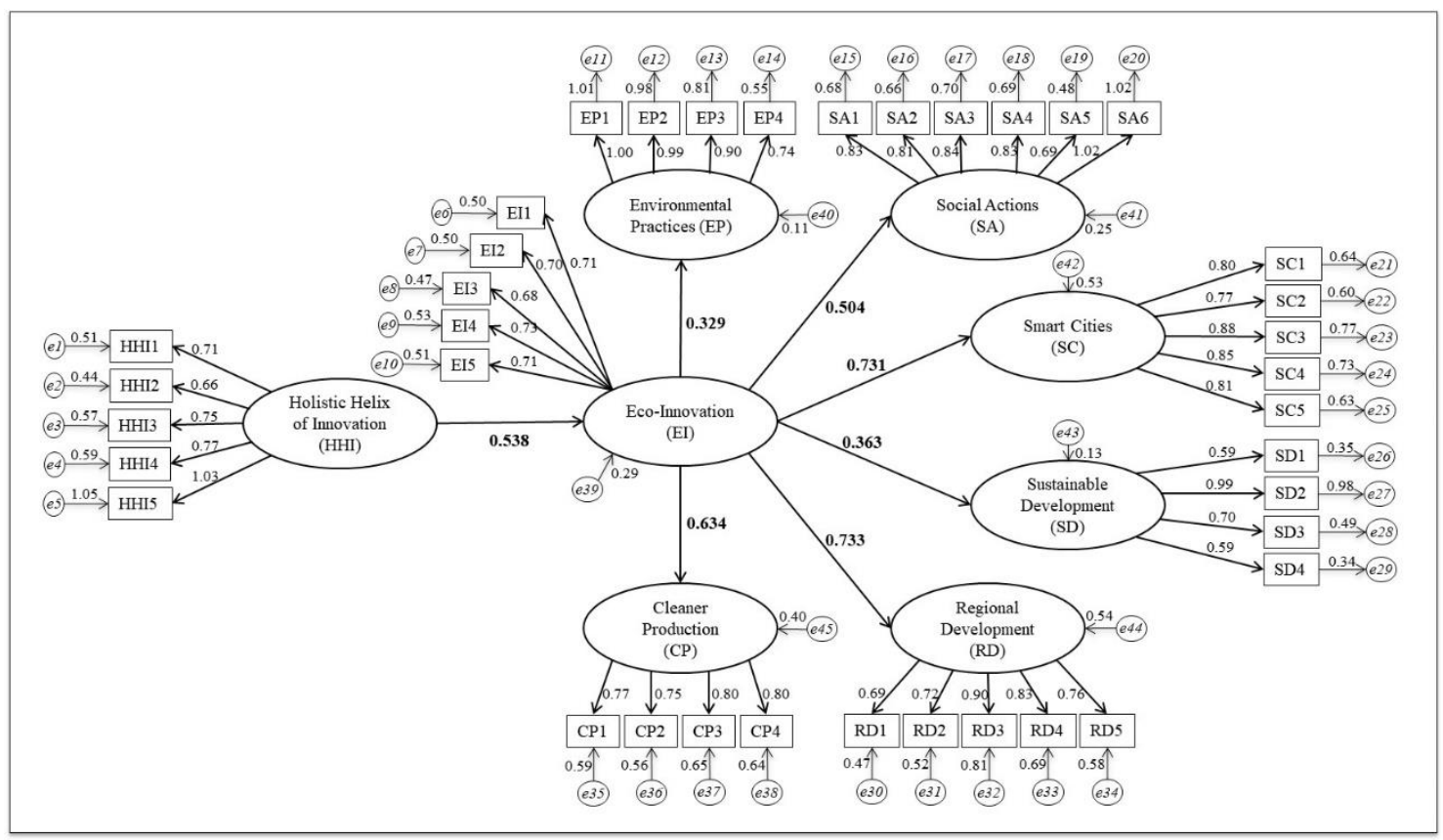

Fig. 2. Integrated Model-Standardized Regression Weights

Table 6

Hypothesis Testing

\begin{tabular}{|c|c|c|c|c|c|c|}
\hline & Constructs & & & $\begin{array}{l}\text { Standardized } \\
\text { Estimate (SE) }\end{array}$ & $\begin{array}{l}\text { Unstandardized } \\
\text { Estimate (UE) }\end{array}$ & $\mathbf{p}$ \\
\hline H1 & $\begin{array}{l}\text { Holistic Helixes of } \\
\text { Innovation }(\mathrm{HHI})\end{array}$ & $\rightarrow$ & Eco-innovation (EI) & 0.538 & 0.453 & $* * *$ \\
\hline $\mathbf{H 2}$ & Eco-innovation (EI) & $\rightarrow$ & $\begin{array}{l}\text { Environmental } \\
\text { Practices (EP) }\end{array}$ & 0.329 & 0.503 & $* * *$ \\
\hline H3 & Eco-innovation (EI) & $\rightarrow$ & $\begin{array}{l}\text { Cleaner Production } \\
\text { (CP) }\end{array}$ & 0.634 & 0.571 & $* * *$ \\
\hline H4 & Eco-innovation (EI) & $\rightarrow$ & Social Actions (SA) & 0.504 & 0.655 & $* * *$ \\
\hline H5 & Eco-innovation (EI) & $\rightarrow$ & $\begin{array}{l}\text { Regional } \\
\text { Development (RD) }\end{array}$ & 0.733 & 0.727 & $* * *$ \\
\hline H6 & Eco-innovation (EI) & $\rightarrow$ & Smart Cities (SC) & 0.731 & 0.824 & $* * *$ \\
\hline H7 & Eco-innovation (EI) & $\rightarrow$ & $\begin{array}{l}\text { Sustainable } \\
\text { Development (SD) }\end{array}$ & 0.363 & 0.222 & $* * *$ \\
\hline
\end{tabular}

*** Significance level $\mathrm{p}<0.001$

The hypothesis tests found important and significant relationships between the constructs studied. The research has shown that the Holistic Helixes of Innovation are important antecedents and directly influence Eco-innovation $(\mathrm{H} 1: \mathrm{HHI} \rightarrow \mathrm{EI})$, with a high intensity ( $\mathrm{SE}=0.538$ ), which corroborates with the studies of Lee and Kim (2016), which states that active interactions in the research and development (R\&D) networks of the institutional players of innovation helixes, such as university-industry-government, can 
improve the innovative capacities of countries. This finding also supports Liu and Huang (2018), argument that universities have a key role to play in the relations of innovation helixes, as they form citizens who will manage organizations.

The theoretical model (Fig. 2) presents as a mediator of the Eco-innovation (EI) relations, proposing that this construct directly influences the constructs Environmental Practices (EP), Cleaner Production (CP), Social Actions (SA), Regional Development RD), Smart Cities (SC) and Sustainable Development (SD), represented by the hypotheses H2 $(\mathrm{EI} \rightarrow \mathrm{EP}), \mathrm{H} 3(\mathrm{EI} \rightarrow \mathrm{CP}), \mathrm{H} 4(\mathrm{EI} \rightarrow \mathrm{SA}), \mathrm{H} 5(\mathrm{EI} \rightarrow \mathrm{RD}), \mathrm{H} 6(\mathrm{EI} \rightarrow \mathrm{SC})$ and $\mathrm{H} 7(\mathrm{EI} \rightarrow \mathrm{SD})$. All hypotheses were supported, with moderate and high intensities of the relationships (Table 5). Among the results, we highlight the high intensity of the EI $\rightarrow \mathrm{RD}$ $(\mathrm{SE}=0.733)$ ratio, which, based on citizens' perception, indicates that sustainable innovation can positively influence the development of the region, since according to studies by Xavier et al. (2017) and Bossle et al. (2016) sustainable innovation stimulates a new business environment that integrates economic and environmental gains, through new processes and competitive business strategies.

Another important aspect of the research results is evidence that EI fundamentals can positively influence the use of Smart Cities precepts. The research confirms that the respondents recognize the $\mathrm{EI} \rightarrow \mathrm{SC}$ relation with a high intensity $(\mathrm{SE}=0.731)$, which contributes with the studies of Caragliu et al. (2011), Fei et al. (2016) and Beretta (2018) on the need to use technological innovations, as well as new communication and information systems, to develop strategies to attend to the increase of urban populations, which causes increased consumption of energy, transport, water, new buildings and public spaces.

In order to evaluate the quality of the integrated model, the adjustment indices of the model (Table 7) were evaluated based on Bentler and Bonett (1980), Bollen (1989), Bentler (1990), McDonald and Marsh (1990), and Hair Jr. et al. (2014). The results of the calculation of all observable variables, in which the values of AVE, Composite Reliability, and KMO are considered satisfactory, however the specific indexes of adjustment of the structural model ( $\square 2 / \mathrm{DF}$, RMSEA, NFI, IFI, TLI, CFI, GFI, AGFI) expressed in Table 7, have low values. These results do not invalidate the hypothesis of the research, it only indicates that the model can be improved, with the inclusion or exclusion of observable variables, as well as with the possibility of inserting in the structural model the possible correlations between the observable variables and between the constructs.

Table 7

Model adjustment indexes

\begin{tabular}{lcccccccccc}
\hline AVE* & $\begin{array}{c}\text { Composite } \\
\text { Reliability* }\end{array}$ & KMO* & $\square$ 2/DF & RMSEA & NFI & IFI & TLI & CFI & GFI & AGFI \\
0.756 & 0.991 & 0.870 & 10.1 & 0.067 & 0.751 & 0.770 & 0.754 & 0.769 & 0.687 & 0.648 \\
\hline
\end{tabular}

* Significance level $\mathrm{p}<0.001$

To assess the moderating effect of the Generations (Baby Boomers, Generation $\mathrm{X}$, Generation Y), we used the analysis of the mean responses in the construct and analysis of variance (ANOVA). Table 8 shows the results of the averages of the respondents for each construct, showing that there is no difference between the Generations in the construct Holistic Helixes of Innovation (HHI), therefore the Generations perceive positive results from government actions and private organizations, however the general mean (3.837) can be considered important, as it is located in the middle third of the 5-point Likert. 
The results expressed in Table 8 (ANOVA) demonstrate that there are differences between the average responses of the Generations, in the constructs EI, EP, CP, SA, RD, SC and SD $(p<0.05)$, therefore these results partially confirm the moderating effect of Generations on the constructs, since the HHI construct did not present significant differences $(\mathrm{p}<0.919)$.

It is noteworthy that the results indicate that the Baby Boomers generation has higher averages in the constructs EP (4.522) and SD (3.714); It was identified that Generation Y has the highest means in the constructs EI (4.258), CP (4.238), AS (3.783), RD (4.092) and SC (4.104).

Table 8

Moderating effect of the generation - Mean and ANOVA

\begin{tabular}{|c|c|c|c|c|}
\hline Constructs & Generation & $\begin{array}{c}\text { Respondents } \\
\mathbf{N}\end{array}$ & Mean & $\begin{array}{l}\text { ANOVA } \\
\text { Sig.* }\end{array}$ \\
\hline \multirow{4}{*}{$\begin{array}{l}\text { Mean Holistic Helixes } \\
\text { of Innovation (HHI) }\end{array}$} & Baby Boomers & 138 & 3.852 & \multirow{4}{*}{0.919} \\
\hline & Mean Generation X & 294 & 3.845 & \\
\hline & Mean Generation Y & 600 & 3.830 & \\
\hline & General Mean & 1032 & 3.837 & \\
\hline \multirow{4}{*}{ Eco-innovation (EI) } & Baby Boomers & 138 & 4.148 & \multirow{4}{*}{0.003} \\
\hline & Mean Generation X & 294 & 4.106 & \\
\hline & Mean Generation Y & 600 & 4.258 & \\
\hline & General Mean & 1032 & 4.200 & \\
\hline \multirow{4}{*}{$\begin{array}{l}\text { Environmental } \\
\text { Practices (EP) }\end{array}$} & Baby Boomers & 138 & 4.522 & \multirow{4}{*}{0.000} \\
\hline & Mean Generation X & 294 & 4.255 & \\
\hline & Mean Generation Y & 600 & 3.883 & \\
\hline & General Mean & 1032 & 4.074 & \\
\hline \multirow{4}{*}{$\begin{array}{l}\text { Cleaner Production } \\
(\mathrm{CP})\end{array}$} & Baby Boomers & 138 & 4.103 & \multirow{4}{*}{0.00} \\
\hline & Mean Generation X & 294 & 3.943 & \\
\hline & Mean Generation Y & 600 & 4.238 & \\
\hline & General Mean & 1032 & 4.136 & \\
\hline \multirow{4}{*}{ Social Actions (SA) } & Baby Boomers & 138 & 3.580 & \multirow{4}{*}{0.000} \\
\hline & Mean Generation X & 294 & 3.224 & \\
\hline & Mean Generation Y & 600 & 3.783 & \\
\hline & General Mean & 1032 & 3.597 & \\
\hline \multirow{4}{*}{$\begin{array}{l}\text { Regional Development } \\
\text { (RD) }\end{array}$} & Baby Boomers & 138 & 3.930 & \multirow{4}{*}{0.000} \\
\hline & Mean Generation X & 294 & 3.841 & \\
\hline & Mean Generation Y & 600 & 4.092 & \\
\hline & General Mean & 1032 & 3.999 & \\
\hline \multirow{4}{*}{ Smart Cities (SC) } & Baby Boomers & 138 & 3.730 & \multirow{4}{*}{0.00} \\
\hline & Mean Generation X & 294 & 3.853 & \\
\hline & Mean Generation Y & 600 & 4.104 & \\
\hline & General Mean & 1032 & 3.983 & \\
\hline \multirow{4}{*}{$\begin{array}{l}\text { Sustainable } \\
\text { Development (SD) }\end{array}$} & Baby Boomers & 138 & 3.714 & \multirow{4}{*}{0.028} \\
\hline & Mean Generation X & 294 & 3.534 & \\
\hline & Mean Generation Y & 600 & 3.629 & \\
\hline & General Mean & 1032 & 3.613 & \\
\hline
\end{tabular}

* Significance level $\mathrm{p}<0.05$.

As an addition to the research, it was verified the possibility of a difference between the averages of the respondents in Brazil and in Portugal (Table 9). With the application of analysis of variance (ANOVA), we identified a significant difference in the constructs EI, EP, CP, SA, RD, SC and SD ( $\mathrm{p}<0.05)$, but in the HHI construct there were no significant differences $(\mathrm{p}<0.488)$ between countries. 
Table 9

Moderating effect of the country - Mean and ANOVA

\begin{tabular}{|c|c|c|c|c|}
\hline Constructs & Generation & $\begin{array}{c}\text { Respondents } \\
\text { N }\end{array}$ & Mean & $\begin{array}{l}\text { ANOVA } \\
\text { Sig.* }\end{array}$ \\
\hline \multirow{3}{*}{$\begin{array}{l}\text { Mean Holistic Helixes } \\
\text { of Innovation (HHI) }\end{array}$} & Brazil & 587 & 3.850 & \multirow{3}{*}{0.488} \\
\hline & Portugal & 445 & 3.820 & \\
\hline & General Mean & 1032 & 3.837 & \\
\hline \multirow{3}{*}{ Eco-innovation (EI) } & Brazil & 587 & 4.235 & \multirow{3}{*}{0.049} \\
\hline & Portugal & 445 & 4.153 & \\
\hline & General Mean & 1032 & 4.200 & \\
\hline \multirow{3}{*}{$\begin{array}{l}\text { Environmental } \\
\text { Practices (EP) }\end{array}$} & Brazil & 587 & 3.879 & \multirow{3}{*}{0.000} \\
\hline & Portugal & 445 & 4.331 & \\
\hline & General Mean & 1032 & 4.074 & \\
\hline \multirow{3}{*}{$\begin{array}{l}\text { Cleaner Production } \\
\text { (CP) }\end{array}$} & Brazil & 587 & 3.748 & \multirow{3}{*}{0.000} \\
\hline & Portugal & 445 & 3.398 & \\
\hline & General Mean & 1032 & 3.597 & \\
\hline \multirow{3}{*}{ Social Actions (SA) } & Brazil & 587 & 4.062 & \multirow{3}{*}{0.000} \\
\hline & Portugal & 445 & 3.915 & \\
\hline & General Mean & 1032 & 3.999 & \\
\hline \multirow{3}{*}{$\begin{array}{l}\text { Regional Development } \\
\text { (RD) }\end{array}$} & Brazil & 587 & 4.142 & \multirow{3}{*}{0.001} \\
\hline & Portugal & 445 & 3.773 & \\
\hline & General Mean & 1032 & 3.983 & \\
\hline \multirow{3}{*}{ Smart Cities (SC) } & Brazil & 587 & 3.667 & \multirow{3}{*}{0.00} \\
\hline & Portugal & 445 & 3.543 & \\
\hline & General Mean & 1032 & 3.613 & \\
\hline \multirow{3}{*}{$\begin{array}{l}\text { Sustainable } \\
\text { Development (SD) }\end{array}$} & Brazil & 587 & 4.221 & \multirow{3}{*}{0.004} \\
\hline & Portugal & 445 & 4.024 & \\
\hline & General Mean & 1032 & 4.136 & \\
\hline
\end{tabular}

* Significance level $\mathrm{p}<0.05$.

In order to evaluate the possible moderating effect of the country (Brazil, Portugal) on the intensity of relations between the variables, the multi-groups analysis was performed (Byrne, 2010), measuring the SE index of the two groups and verifying if a statistically significant difference in the Chi-square ( $\square 2$ ). In Table 10 it can be observed that there is a significant difference in the relationships between the constructs standing out in the relation between $\mathrm{EI} \rightarrow \mathrm{EP}$ Portugal $(\mathrm{SE}=0.237)$ presents a low intensity, in the same way the respondents of Brazil $(\mathrm{SE}=0.279)$ present a low intensity in the $\mathrm{EI} \rightarrow \mathrm{SD}$ relationship, however, the results of these relations are important and the hypotheses in the two countries were confirmed.

Table 10

Moderating effect of the country - multi-groups analysis

\begin{tabular}{|c|c|c|c|c|c|c|}
\hline & Constructs & & & $\begin{array}{c}\text { Brazil } \\
\text { SE }^{\mathbf{a}}\end{array}$ & $\begin{array}{l}\text { Portugal } \\
\text { SE }^{\mathrm{a}}\end{array}$ & $\begin{array}{c}\text { Chi-square } \\
\text { ( } \square \text { 2) difference } \\
\text { p }\end{array}$ \\
\hline H1 & $\begin{array}{l}\text { Holistic Helixes of } \\
\text { Innovation (HHI) }\end{array}$ & $\rightarrow$ & $\begin{array}{l}\text { Eco-innovation } \\
\text { (EI) }\end{array}$ & 0.500 & 0.612 & $* * *$ \\
\hline H2 & $\begin{array}{l}\text { Eco-innovation } \\
(\mathrm{EI})\end{array}$ & $\rightarrow$ & $\begin{array}{l}\text { Environmental } \\
\text { Practices (EP) }\end{array}$ & 0.445 & 0.237 & $* * *$ \\
\hline H3 & $\begin{array}{l}\text { Eco-innovation } \\
\text { (EI) }\end{array}$ & $\rightarrow$ & $\begin{array}{l}\text { Cleaner Production } \\
(\mathrm{CP})\end{array}$ & 0.493 & 0.707 & $* * *$ \\
\hline H4 & $\begin{array}{l}\text { Eco-innovation } \\
\text { (EI) }\end{array}$ & $\rightarrow$ & $\begin{array}{l}\text { Social Actions } \\
\text { (SA) }\end{array}$ & 0.598 & 0.386 & $* * *$ \\
\hline H5 & $\begin{array}{l}\text { Eco-innovation } \\
\text { (EI) }\end{array}$ & $\rightarrow$ & $\begin{array}{l}\text { Regional } \\
\text { Development (RD) }\end{array}$ & 0.852 & 0.560 & $* * *$ \\
\hline H6 & $\begin{array}{l}\text { Eco-innovation } \\
\text { (EI) }\end{array}$ & $\rightarrow$ & Smart Cities (SC) & 0.766 & 0.714 & $* * *$ \\
\hline
\end{tabular}




\begin{tabular}{|c|c|c|c|c|c|c|}
\hline H7 & $\begin{array}{l}\text { Eco-innovation } \\
\text { (EI) }\end{array}$ & $\rightarrow$ & $\begin{array}{l}\text { Sustainable } \\
\text { Development (SD) }\end{array}$ & 0.279 & 0.354 & $* * *$ \\
\hline
\end{tabular}

a Standardized Estimate (SE)

*** Significance level $\mathrm{p}<0.001$

\section{Conclusion}

The main contribution of the research is to evidence that Holistic Helixes of Innovation (HHI) are predictors of the process of sustainable innovation, which is expressed in this research in the Eco-innovation (EI) construct. In this study, the important influence of HHI on IE in Brazil and Portugal was identified, demonstrating that this is not a phenomenon of local perception, but something that is perceived in different contexts. This finding can contribute to the promotion of public policies to encourage integration among HHI stakeholders: Universities, Government, Transformation Industries, Technology Parks, Spin-offs, Incubators, Startup, Consulting Teams, Non-Governmental Organizations, Company Shareholders, Suppliers, and Customers.

\subsection{Theoretical implications}

The integration between the different HHI agents can generate EI that consequently positively influences the promotion of Environmental Practices (EP), Cleaner Production (CP), Social Actions (SA), Regional Development (RD), Smart Cities (SC) and Sustainable Development (SD). In this context, the research contributes to the advancement of science by proving that, in individuals' perceptions, EI is a strategic drive to significantly increase people's quality of life elements, such as RD, SC, SA, and SD, as well as EI is a potentiator of environmental sustainability, which was measured using $\mathrm{EP}$ and $\mathrm{CP}$ constructs.

The survey results indicate that Generation Y perceives greater importance of EI, $\mathrm{CP}, \mathrm{AS}, \mathrm{RD}$, and SC, which can be evidenced in the analysis of the mean responses in the constructs. These results demonstrate Generation Y's greater sensitivity to situations involving socio-environmental responsibility and Sustainable Development, which increases confidence in new generations so that they can act and create conditions for a sustainable future.

The moderating effect of the country (Brazil, Portugal) on the intensity of the relationships between the variables, can be seen in Table 10, in which it is identified, that for residents in Brazil, EI exerts a strong influence on AS, RD and SC. Therefore, this study contributes to science by concluding that the EI precepts are vectors for increasing socio-environmental practices, transforming cities into Smart Cities, and contribute to sustainable regional development.

Another important academic contribution of the research is the provision of an Analysis Framework with the measurement model and the structural model, which has been validated statistically (observable variables and constructs). The integrated model (Framework) proposed in the research can be replicated in different regional contexts.

\subsection{Practical Implications}

Regarding the managerial contributions of the research, we highlight the identification of the predictors of PE and CP, which are the constructs of HHI and EI. In this sense, organizations should focus on the dissemination of environmental actions promoted by companies to increase the potential value of the company's brand, which has already been proven in the studies of Severo et al. (2018).

The identification of the positive influence of IE precepts on the concepts of Smart Cities, in the aspects of sustainability and quality of life in urban centers, indicate the 
need for city managers to use technological innovations in the management of the demands of transport, energy, water and others public resources. Therefore, the research results contribute to the understanding that innovation must be designed to improve people's quality of life through the integration of technologies and environmental sustainability.

Another managerial contribution is linked to the interpretation that the EI precepts are key to trigger positive influences on socio-environmental aspects, smart cities and regional and sustainable development. In this sense, organizations and governments can contribute to society, with greater efficiency, allocating resources in projects that develop socio-environmental innovations.

\subsection{Search limitations and future studies}

The research presents important findings, however, there are limitations related to data collection, from the exclusive perception of individuals. This perception of individuals with the use of a Likert Scale can allow response biases, such as the misleading generalization (Halo effect) and Common-Method Variance (CMV) described by Bagozzi and Yi (1991), Podsakoff et al. (2003) and Richardson et al. (2009). In this sense, the data were statistically validated with the use of tests of normality, simple reliability, composite reliability, tests of variance and the application of the Confirmatory Factor Analysis Marker proposed by Williams et al. (2003a; 2003b) to identify the possible CMV occurrence.

Another limitation of the research refers to the countries chosen for the study, as Brazil and Portugal are at different levels of economic and social development, since Brazil is still considered in a country in the "development" phase, while Portugal is a nation that is part of the European Union, already with a higher level of development. This may have interfered with the variation in results when comparing the two countries. However, this limitation does not compromise the results and reinforces the moderating effect of the respondents' residence.

Based on the findings of the research, we suggest new studies that identify other mediating factors and moderators, in order to understand the elements that can effectively promote regional development and sustainable development. For it is relevant for science to know the variables that can help governments and other organizations to develop policies and actions to promote the improvement of people's quality of life from a longterm triple bottom line perspective.

\section{References}

Aldieri, L., Carlucci, F., Cirà, A., Ioppolo, G., \& Vinci, C. P. (2019). Is green innovation an opportunity or a threat to employment? an empirical analysis of three main industrialized areas: the USA, japan and Europe. Journal of Cleaner Production, 214, 758-766.

Akbari, M., Mehrali, M., SeyyedAmiri, N., Rezaei, N., \& Pourjam, A. (2019). "Corporate social responsibility, customer loyalty and brand positioning", Social Responsibility Journal, 16(5), 671-689

Akhras, C. (2015). Millennials: entitled networking business leaders. International Journal of Computer Science and Business Informatics, 15 (1), 1694-2108.

Bagozzi, R.P., \& Yi, Y. (1991). Multitrait-multimethod matrices in consumer research. Journal of Consumer Research, 17 (4), 426-439.

Barbieri, R., \& Santos, D. F. L. (2020). Sustainable business models and eco-innovation: A life cycle assessment. Journal of Cleaner Production, 266, 121954. 
Bentler, P.M. (1990). Comparative fit indexes in structuralequations. Psychological Bulletin, 107 (2), 238 246.

Bentler, P.M., \& Bonett, D.G. (1980). Significance tests and goodness of fit in the analysis of covariance structures. Psychological Bulletin, 88, 588-606.

Beretta, I. (2018). The social effects of eco-innovations in Italian smart cities. Cities, 72, 115-121.

Bollen, K.A. (1989). A new incremental fit index for general structural equation models. Sociological Methods and Research, 17, 303-316.

Bossle, M.B., De Barcellos, M.D., Vieira, L.M., \& Sauvée, L. (2016). The drivers for adoption of ecoinnovation. Journal of Cleaner Production, 113,861-872.

Brem, A., \& Radziwon, A. (2017). Efficient Triple Helix collaboration fostering local niche innovation projects - a case from Denmark. Technological Forecasting and Social Change, 123, 130-141.

Byrne, B.M. (2010). Structural equation modeling with AMOS: basic concepts, applications and programming. 2nd ed. Taylor \& Francis Group, New York.

Cai, W., \& Li, G. (2018). The drivers of eco-innovation and its impact on performance: Evidence from China. Journal of Cleaner Production, 176, 110-118.

Cancino, C. A., La Paz, A. I., Ramaprasad, A., \& Syn, T. (2018). Technological innovation for sustainable growth: an ontological perspective. Journal of Cleaner Production, 179, 31-41.

Carayannis,E. G., \& Campbell, D. F. (2009). 'Mode 3'and'Quadruple Helix': toward a 21 st century fractal innovation ecosystem. International Journal of Technology Management, 46 (3-4), 201-234.

Carayannis,E.G., \& Campbell, D.F. (2010). Triple Helix, Quadruple Helix and Quintuple Helix and how do knowledge, innovation and the environment relate to each other?: a proposed framework for a transdisciplinary analysis of sustainable development and social ecology. International Journal of Social Ecology and Sustainable Development, 1 (1), 41-69.

Carayannis, E.G., Cherepovitsyn, A.E., \& Ilinova, A.A. (2017). Sustainable development of the Russian arctic zone energy shelf: the role of the quintuple innovation helix model. Journal of the Knowledge Economy, 8 (2), 456-470.

Caragliu, A., Del Bo, C., \& Nijkamp,P. (2011). Smart cities in Europe. Journal of Urban Technology, 18 (2), 65-82.

Carrillo-Hermosilla, J., del Río González, P., \& Könnölä, T. (2009). Eco-innovation: when sustainability and competitiveness shake hands. Palgra ve Macmillan, New York. Doi: 10.1057/9780230244856

Chen, J., Cheng, J., \& Dai, S. (2017). Regional eco-innovation in China: An analysis of eco-innovation levels and influencing factors. Journal of Cleaner Production, 153, 1-14.

Chen, X., Yi, N., Zhang, L., \& Li, D. (2018). Does institutional pressure foster corporate green innovation? Evidence from China's top 100 companies. Journal of Cleaner Production, 188, 304-311.

Chen, L., Zhang, X., He, F., \& Yuan, R. (2019). Regional green development level and its spatial relationship under the constraints of haze in China. Journal of Cleaner Production, 210, 376-387.

Cheng, C.C. \& Shiu, E. C. (2012). Validation of a proposed instrument for measuring eco-innovation: An implementation perspective. Technovation, 32 (6), 329-344.

Cheng, C.C., Yang, C.L. \& Sheu, C. (2014). The link between eco-innovation and business performance: a Taiwanese industry context. Journal of Cleaner Production, 64, 81-90.

Colombo, L.A., Pansera, M., \& Owen, R. (2019). The discourse of eco-innovation in the European Union: 
an analysis of the Eco-Innovation Action Plan and Horizon 2020. Journal of Cleaner Production.214,653665. DOI: https://doi.org/10.1016/j.jclepro.2018.12.150

Cong, W., \& Shi, L. (2018). Heterogeneity of industrial development and evolution of cleaner production: bibliometric proof based on JCLP. Journal of Cleaner Production, 212, 822-836.

De Guimarães, J.C.F., Dorion, E.C.H., \& Severo, E.A. (2019). Antecedents, mediators and consequences of sustainable operations: A framework for analysis of the manufacturing industry. Benchmarking: An International Journal, In Press https://doi.org/10.1108/BIJ-09-2018-0296

De Guimarães, J.C.F., Severo, E.A., Dorion, E.C.H., Coallier, F., \& Olea, P.M. (2016). The use of organizational resources for product innovation and organizational performance: a survey of the brazilian furniture industry. International Journal of Production Economics, 180, 135-147.

De Guimarães, J.C.F., Severo, E.A., \& De Vasconcelos, C.R.M. (2018). The influence of entrepreneurial, market, knowledge management orientations on cleaner production and the sustainable competitive advantage. Journal of Cleaner Production, 174, 1653-1663.

De Guimarães, J.C., Severo, E.A., Júnior, L.A.F., Da Costa, W.P.L.B., \& Salmoria, F.T. (2020). Governance and quality of life in smart cities: Towards sustainable development goals. Journal of Cleaner Production, 253,119926.

Del Baldo, M. (2019). Acting as a benefit corporation and a B Corp to responsibly pursue private and pu blic benefits. The case of Paradisi Srl (Italy). International Journal of Corporate Social Responsibility, 4(1), 4.

Dieste, M., Panizzolo, R., \& Garza-Reyes, J. A. (2020). Evaluating the impact of lean practices on environmental performance: evidences from five manufacturing companies. Production Planning \& Control,31(9), 739-756.

Dong, L., Tong, X., \& Li, X. (2018). Some developments and new insights of environmental problems and deep mining strategy for cleaner production in mines. Journal of Cleaner Production, 210, 1562-1578.

Dudin, M.N., Frolova, E.E., Gryzunova, N.V., \& Shuvalova, E.B. (2015). The Triple helix model as a mechanism for partnership between the state, business, and the scientific-educational community in the area of organizing national innovation development. Asian Social Science, 11 (1), 230-238.

Etzkowitz, H., \& Leydesdorff, L. (1995). The triple helix-university-industry-government relations: a laboratory for knowledge-based economic development. European Association Study Science and Technology Review, 14 (1), 14-19.

Etzkowitz, H., \& Leydesdorff, L. (2000). The dynamics of innovation: from National Systems and "Mode 2" to a Triple Helix of university-industry-government relations. Research Policy, 29 (2), 109-123.

European Commission, (2018). Eco-innovation: when business meets the environment. DG Environment. (accessed January 2019). http://ec.europa.eu/environment/eco innovation/discover/programme/index_en.htm

Fei, J., Wang, Y., Yang, Y., Chen, S., \& Zhi, Q. (2016). Towards eco-city: the role of green innovation. Energy Procedia, 104, 165-170.

Fornell, C., \& Larcker, D.F. (1981). Structural equation models with unobservable variables and measurement error. Journal of Marketing Research, 17 (1), 39-50.

Fraj, E., \& Martinez, E. (2007). Ecological consumer behaviour: an empirical analysis. International Journal of Consumer Studies, 31 (1), 26-33.

García-Granero, E.M., Piedra-Muñoz, L., \& Galdeano-Gómez,E. (2018). Eco-innovation measurement: A review of firm performance indicators. Journal of Cleaner Production, 191, 304-317.

García-Granero, E. M., Piedra-Muñoz, L., \& Galdeano-Gómez, E. (2020). Measuring eco-innovation 
dimensions: The role of environmental corporate culture and commercial orientation. Research Policy, 49(8), 104028.

Geng, D., Lai, K. H., \& Zhu, Q. (2020). Eco-innovation and its role for performance improvement among Chinese small and medium-sized manufacturing enterprises. International Journal of Production Economics, 107869.

Giannetti, B. F., Coscieme, L., Agostinho, F., Neto, G. O., Almeida, C. M. V. B., \& Huisingh, D. (2018). Synthesis of the discussions held at the International Workshop on Advances in Cleaner Production: Ten years working together for a sustainable future. Journal of Cleaner Production, 183, 481-486.

Gold, S., Muthuri, J.N., \& Reiner, G. (2018). Collective action for tackling "wicked" social problems: A system dynamics model for corporate community involvement. Journal of Cleaner Production, 179, 662673.

Gouvea, R., Kassicieh, S., \& Montoya, M.J.R. (2013). Using the quadruple helix to design strategies for the green economy. Technological Forecasting and Social Change, 80 (2), 221-230.

Grundel, I., \& Dahlström, M. (2016). A Quadruple and Quintuple Helix approach to regional innovation systems in the transformation to a forestry-based bioeconomy. Journal of the Knowledge Economy, 7 (4), 963-983.

Guerrero, M., Urbano, D., 2017. The impact of Triple Helix agents on entrepreneurial innovations' performance: An inside look at enterprises located in an emerging economy. Technological Forecasting and Social Change, 119, 294-309.

Hair Jr. J. F., Black, W. C., Bardin, B. J., \& Anderson, R. E. (2014). Multivariate data analysis: Pearson new international edition. 7th ed. Pearson Education Limited, New York.

Halkos, G., \& Skouloudis, A. (2018). Corporate social responsibility and innovative capacity: Intersection in a macro-level perspective. Journal of Cleaner Production, v. 182, 291-300.

Henseler, J., Ringle, C.M., \& Sarstedt, M. (2014). A new criterion for assessing discriminant validity in variance-based structural equation modeling. Journal of the Academy of Marketing Science, 43 (1), 115135 .

Hojnik, J., \& Ruzzier, M. (2016). What drives eco-innovation? A review of an emerging literature. Environmental Innovation and Societal Transitions, 19,31-41.

Hojnik, J., Ruzzier, M., \& Manolova, T.S. (2018). Internation alization and economic performance: The mediating role of eco-innovation. Journal of Cleaner Production, 171, 1312-1323.

Ikram, M., Sroufe, R., Rehman,E., Shah, S. Z. A., \& Mahmoudi, A. (2020a). Do quality, environmental, and social (QES) certifications improve international trade? A comparative grey relation analysis of developing vs. developed countries. Physica A: Statistical Mechanics and its Applications, 545, 123486.

Ikram, M., Zhang, Q., Sroufe, R., \& Shah, S. Z. A. (2020b). Towards a sustainable environment: the nexus between ISO 14001, renewable energy consumption, access to electricity, agriculture and CO2 emissions in SAARC countries. Sustainable Production and Consumption, 22, 218-230.

Ikram, M., Zhou, P., Shah, S. A. A., \& Liu, G. Q. (2019). Do environmental management systems help improve corporate sustainable development? Evidence from manufacturing companies in Pakistan. Journal of Cleaner Production, 226, 628-641.

Jamali, D.R., El Dirani, A.M., \& Harwood, I.A. (2015). Exploring human resource management roles in corporate social responsibility: the CSR-HRM co-creation model. Business Ethics: A European Review, 24 (2), 125-143.

Kanda, W., Hjelm, O., Clausen, J., \& Bienkowska, D. (2018). Roles of intermediaries in supporting ecoinnovation. Journal of Cleaner Production, 205, 1006-1016. 
Kiefer, C. P., Del Río González, P., \& Carrillo-Hermosilla, J. (2018). Drivers and barriers of eco-innovation types for sustainable transitions: a quantita tive perspective. Business Strategy and the Environment, 28 (1), 155-172.

Kline, R.B., 2011. Principles and practice of structural equation modeling. 3 ed. The Guilford Press. New York.

Kumar, A., \& Anbanandam, R. (2019). Development of social sustainability index for freight transportation system. Journal of Cleaner Production, 210,77-92.

Li, Y., Arora, S., Youtie, J., \& Shapira,P. (2018). Using web mining to explore Triple Helix influences on growth in small and mid-size firms. Technovation, 76, 3-14.

Lim, C., Kim, K.J., \& Maglio, P.P. (2018). Smart cities with big data: reference models, challenges, and considerations. Cities, 82, 89-99.

Lin, Z., Wang, S., \& Yang, L. (2020). Motivating innovation alliance's environmental performance through eco-innovation investment in a supply chain. Journal of Cleaner Production, 122361.

Lissitsa, S. \& Kol, O. (2016). Generation X vs. generation Y: a decade of online shopping. Journal of Retailing and Consumer Services, 31, 304-312.

Liu, Y., \& Huang, Q. (2018). University capability as a micro-foundation for the Triple Helix model: the case of China. Technovation, 76-77, 40-50.

López-González, E., Martínez-Ferrero, J., \& García-Meca, E. (2019). Corporate social responsibility in family firms: A contingency approach. Journal of Cleaner Production, 211, 1044-1064.

López, F. J. D., \& Montalvo, C. (2015). A comprehensive review of the evolving and cumulative nature of eco-innovation in the chemical industry. Journal of Cleaner Production, 102, 30-43.

Loosemore, M., Lim, B.T.H., Ling, F.Y.Y., \& Zeng, H.Y. (2018). A comparison of corporate social responsibility practices in the Singapore, Australia and New Zealand construction industries. Journal of Cleaner Production, 190, 149-159.

Low, M.P., \& Siegel, D. (2019). A bibliometric analysis of employee-centred corporate social responsibility research in the 2000s. Social Responsibility Journal, 16(5), 691-717.

Machado Jr., C., Ribeiro, D.M.N.M., Da Silva Pereira, R., \& Bazanini, R. (2018). Do Brazilian cities want to become smart or sustainable?. Journal of Cleaner Production, 199, 214-221.

Mardia, K.V. (1971). The effect of nonnorma lity on some multivariate tests and robustness to nonnormality in the linear model. Biometrika, 58 (1), 105-121.

Marôco, J. (2010). Análise de equações estruturais: fundamentos teóricos, softwares \& aplicações. PSE, Lisboa.

Martins, V. W. B., Rampasso,I.S., Siltori, P. F. S., Cazeri, G. T., Anholon, R., Quelhas, O. L. G., \& Leal Filho, W. (2020). Contributions from the Brazilian industrial sector to Sustainable Development. Journal of Cleaner Production, 122762.

Mascarenhas, C., Marques, C., \& Ferreira, J. J. (2020). One for all and all for one: collaboration and cooperation in triple helix knowledge cocreation. International Regional Science Review, 43(4), 316-343.

McDonald, R.P. \& Marsh, H. W. (1990). Choosing a multivariate model: noncentrality and goodness of fit. Psychological Bulletin, 107, 247-255.

Nilssen, M. (2019). To the smart city and beyond? Developing a typology of smart urban innovation. Technological Forecasting and Social Change, 142,98-104.DOI: 10.1016/j.techfore.2018.07.060 
Peiró-Signes, Á., \& Segarra-Oña,M. (2018). How past decisions affect future behavior on eco-innovation: An empirical study. Business Strategy and the Environment, 27 (8), 1233-1244.

Pestana, M.H., \& Gageiro, J.N. (2014). Análise de dados para ciências sociais: a complementariedade do SPSS. 6th ed. Sílabo, Lisboa.

Pialot, O., \& Millet, D. (2018). Towards operable criteria of eco-innovation and eco-ideation tools for the early design phases. Procedia CIRP, 69, 692-697.

Pinto, G.M.C., Pedroso, B., Moraes, J., Pilatti, L.A., \& Picinin, C.T. (2018). Environmental management practices in industries of Brazil, Russia, India, China and South Africa (BRICS) from 2011 to 2015. Journal of Cleaner Production, 198, 1251-1261.

Podsakoff, P.M., Mackenzie, S.B., Lee, J., \& Podsakoff, N. P. (2003). Common method biases in behavioral research: a critical review of the literature and recommended Remedies. Journal of Applied Psychology, 88 (5), 879-903.

Rake, M., \& Grayson, D. (2009). Embedding corporate responsibility and sustainability-everybody's business. Corporate Governance: The international journal of business in society, 9 (4), 395-399.

Razak, A. A., \& White, G. R. (2015). The Triple Helix Model for Innovation: A holistic ex ploration of barriers and enablers. International Journal of Business Performance and Supply Chain Modelling, 7(3), 278-291.

Richardson,H.A., Simmering, M.J., \& Sturman, M.C. (2009). A tale of three perspectives: Examining post hoc statistical techniques for detection and correction of common method variance. Organizational Research Methods, 12 (4), 762-800.

Roome, N. (2011). A retrospective on globalization and sustainable development: the business challenge of systems organization and systems integration. Business \& Professional Ethics Journal, 195-230.

Salim, N., Ab Rahman, M. N., \& Abd Wahab, D. (2019). A systematic literature review of internal capabilities for enhancing eco-innovation performance of manufacturing firms. Journal of Cleaner Production, 209, 1445-1460.

Sato, S. (2017). Climate change, the built environment and triple-helix innovation. Energy Procedia, 143, 843-850.

Severo, E.A., De Guimarães, J.C.F., Dellarmelin, M. L., \& Ribeiro, R. P. (2019). The influence of social networks on environmental awareness and the social responsibility of generations. Brazilian Business Review, 16 (5), 500-518.

Severo, E.A., De Guimarães, J.C.F., \& Dorion, E.C.H. (2018). Cleaner production, social responsibility and eco-innovation: generations' perception for a sustainable future. Journal of Cleaner Production, 186, 91-103.

Severo, E.A., Dorion, E.C.H., \& Guimarães, J.C.F.D. (2017). In novation and environmental sustainability: analysis in Brazilian metal-mechanic industry. International Journal of Innovation and Sustainable Development, 11(2-3), 230-248.

Severo, E.A., \& Guimarães, J.C.F.D. (2015). Corporate environmentalism: an empiric al study in Brazil. International Journal of Business and Globalisation, 15(1), 81-95.

Shu, H., \& Xiong, P. (2018). The Gini coefficient structure and its a pplication for the evaluation of regional balance development in China. Journal of Cleaner Production, 199, 668-686.

Shulla, K., Leal Filho, W., Sommer, J. H., Salvia, A. L., \& Borgemeister, C. (2020). Channels of collaboration for citizen science and the sustainable development goals. Journal of Cleaner Production, 121735 . 
Snijders, T. A. (1992). Estimation on the basis of snowball samples: how to weight?. Bulletin of Sociological Methodology, 36 (1), 59-70.

Strauss, W., \& Howe, N. (1991). Generations. William Morrow, New York.

Tamvada, M. (2020). Corporate social responsibility and accountability: a new theoretical foundation for regulating CSR. International Journal of Corporate Social Responsibility, 5, 1-14.

Tamayo-Orbegozo, U., Vicente-Molina, M-A., \& Villarreal-Larrinaga, O. (2017). Eco-innovation strategic model. A multiple-case study from a highly eco-innovative European region. Journal of Cleaner Production, 142, 1347-1367.

Tanaka, J.S., \& Huba, G.J. (1985). A fit index for covariance structure models under arbitrary GLS estimation. British Journal of Mathematical and Statistical Psychology, 38, 197-201.

Vieira, A. P., \& Radonjič, G. (2020). Disclosure of eco-innovation activities in European large companies' sustainability reporting. Corporate Social Responsibility and Environmental Management,1-14. https://doi.org/10.1002/csr.1961

Voegtlin, C., \& Greenwood, M. (2016). Corporate social responsibility and human resource management: A systematic review and conceptualanalysis. Human Resource Management Review, 26 (3), 181-197.

Wang, L., Chang, H. L., Rizvi, S. K. A., \& Sari, A. (2020). Are eco-innovation and export diversification mutually exclusive to control carbon emissions in G-7 countries?. Journal of Environmental Management, $270,110829$.

Williams, L.J., Edwards, J.R., \& Vandenberg, R.J. (2003a). Recent advances in causalm odeling methods for organizational and management research. Journal of management, 29 (6), 903-936.

Williams, L.J., Hartman, N., \& Cavazotte, F. (2003b). Method variance and marker variables: an integrative approach using structural equation methods. In annual meeting of the Academy of Management. Seattle, WA.

Wong, C. W., Wong, C. Y., \& Boon-itt, S. (2020). Environmental management systems, practices and outcomes: Differences in resource allocation between small and large firms. International Journal of Production Economics, 107734.

Xavier, A.F., Naveiro, R.M., Aoussat, A., \& Reyes, T. (2017). Systematic literature review of ecoinnovation models: opportunities and recommendations for future research. Journal of Cleaner Production, $149,1278-1302$.

Yang, Y., Holgaard, J. E., \& Remmen, A. (2012). What can triple helix frameworks offer to the analysis of eco-innovation dynamics? Theoretical and methodological considerations. Science and Public Policy, 39(3), 373-385.

Yoda, N., \& Kuwashima, K. (2020). Triple helix of university-industry-government relations in Japan: Transitions of collaborations and interactions. Journal of the Knowledge Economy, 11(3), p. 1120-1144.

You, D., Zhang, Y., \& Yuan, B. (2019). Environmental regulation and firm eco-innovation: Evidence of moderating effects of fiscal decentralization and political competition from listed Chinese industrial companies. Journal of Cleaner Production, 207, 1072-1083.

Yu, X., Yan, J., Zhang, F., Hamma, M., \& Zhang, Q. (2020). Sustainable development of sci-tech service intermediaries based on triple helix model of innovation. International Journal of Sustainable Development and Planning, 15(4), p. 513-519.

Yuan, J., Chen, K., Li, W., Ji, C., Wang, Z., \& Skibniewski, M. J. (2018). Social network analy sis for social risks of construction projects in high-density urban areas in China. Journal of Cleaner Production, 198, 940-961. 
Zahari, A. R., \& Esa, E. (2016). Motivation to adopt renewable energy among generation Y. Procedia Economics and Finance, 35, 444-453.

Zhang, P., Duan, N., Dan, Z., Shi, F., \& Wang, H. (2018). An understandable and practicable cleaner production assessment model. Journal of Cleaner Production, 187, 1094-1102.

Zhao, Y., Tan, Y., \& Feng, S. (2020). Does reducing air pollution improve the progress of sustainable development in China?. Journal of Cleaner Production, 122759.

Zheng, C., Yuan, J., Zhu, L., Zhang, Y., \& Shao, Q. (2020). From digital to sustainable: A scientometric review of smart city literature between 1990 and 2019. Journal of Cleaner Production, 120689.

Zopiaris, A. M., Krambia-Kapardis, M., \& Varnavas, A. (2012). Y-ers, X-ers, and Boomers: Investigating the multigenerational [mis]perceptions in the hospitality workplace. Tourism and Hospitality Research, 12 (2), 101-121.

\section{Contribution of authors}

Every author should account for at least one component of the work. Paper approved for publication need to specify the contribution of every single author.

\begin{tabular}{|l|c|c|c|c}
\hline \multicolumn{1}{|c|}{ Contribution } & [Author 1] & [Author 2] & & \\
\hline 1. Definition of research problem & $\sqrt{ }$ & & & \\
\hline $\begin{array}{l}\text { 2. Development of hypotheses or research } \\
\text { questions (empirical studies) }\end{array}$ & $\sqrt{ }$ & & & \\
\hline $\begin{array}{l}\text { 3. Development of theoretical propositions } \\
\text { (theoretical work) }\end{array}$ & $\sqrt{ }$ & $\sqrt{ }$ & & \\
\hline 4. Theoretical foundation / Literature review & $\sqrt{ }$ & $\sqrt{ }$ & & \\
\hline 5. Definition of methodological procedures & $\sqrt{ }$ & $\sqrt{ }$ & & \\
\hline 6. Data collection & $\sqrt{ }$ & $\sqrt{ }$ & & \\
\hline 7. Statistical analysis & $\sqrt{ }$ & $\sqrt{ }$ & & \\
\hline 8. Analysis and interpretation of data & $\sqrt{ }$ & $\sqrt{ }$ & & \\
\hline 9. Critical revision of the manuscript & $\sqrt{ }$ & $\sqrt{ }$ & & \\
\hline 10. Manuscript writing & $\sqrt{ }$ & $\sqrt{ }$ & & \\
\hline 11. Other (plea se specify) & & & & \\
\hline
\end{tabular}

